\title{
The Contribution of Genetic Factors to Cognitive Impairment and Dementia: Apolipoprotein E Gene, Gene Interactions, and Polygenic Risk
}

\author{
Jialing Fan ${ }^{1,2,+}$, Wuhai Tao ${ }^{1,2,+}$, Xin $\mathrm{Li}^{1,2}, \mathrm{He} \mathrm{Li}^{2,3}$, Junying Zhang ${ }^{2,3}$, Dongfeng Wei ${ }^{2,3}$, \\ Yaojing Chen ${ }^{1,2, *}$ and Zhanjun Zhang ${ }^{1,2, *}$ \\ 1 State Key Laboratory of Cognitive Neuroscience and Learning, Beijing Normal University, \\ Beijing 100875, China; jialingfan@foxmail.com (J.F.); twh621@foxmail.com (W.T.); \\ emmalee4539@163.com (X.L.) \\ 2 BABRI Centre, Beijing Normal University, Beijing 100875, China; her2003@163.com (H.L.); \\ zhangjuny1985@163.com (J.Z.); weidongfeng@aliyun.com (D.W.) \\ 3 Institute of Basic Research in Clinical Medicine, China Academy of Chinese Medical Sciences, \\ Beijing 100700, China \\ * Correspondence: zhang_rzs@bnu.edu.cn (Z.Z.); luckychen1989@gmail.com (Y.C.); \\ Tel.: +86-010-5880-2005 (Z.Z.); Tel.: +86-010-5880-3882 (Y.C.) \\ + These authors contributed equally to this work.
}

Received: 22 February 2019; Accepted: 26 February 2019; Published: 7 March 2019 updates

\begin{abstract}
Alzheimer's disease (AD) is a progressive neurodegenerative disease. Although it has been studied for years, the pathogenesis of AD is still controversial. Genetic factors may play an important role in pathogenesis, with the apolipoprotein $\mathrm{E}(A P O E)$ gene among the greatest risk factors for $\mathrm{AD}$. In this review, we focus on the influence of genetic factors, including the APOE gene, the interaction between $A P O E$ and other genes, and the polygenic risk factors for cognitive function and dementia. The presence of the APOE $\varepsilon 4$ allele is associated with increased AD risk and reduced age of AD onset. Accelerated cognitive decline and abnormal internal environment, structure, and function of the brain were also found in $\varepsilon 4$ carriers. The effect of the $A P O E$ promoter on cognition and the brain was confirmed by some studies, but further investigation is still needed. We also describe the effects of the associations between $A P O E$ and other genetic risk factors on cognition and the brain that exhibit a complex gene-gene interaction, and we consider the importance of using a polygenic risk score to investigate the association between genetic variance and phenotype.
\end{abstract}

Keywords: Alzheimer's disease; $A P O E$; cognition; brain structure; brain function; polygenic risk score

\section{Introduction}

\subsection{Alzheimer's Disease and Genetics}

Alzheimer's disease (AD) is a chronic progressive neurodegenerative disease characterized by memory loss and deficits in other cognitive abilities and is the most common form of dementia. With the increase in life expectancy, the prevalence of dementia rose gradually in recent years. The World Alzheimer Report 2018 estimated that, around the world, there will be one new case of dementia every three seconds; 50 million people worldwide are living with dementia in 2018, and that number will be more than 152 million by 2050. The total estimated worldwide cost of dementia in 2018 was one trillion United states dollars (US\$), and this figure will rise to two trillion US\$ by 2030 [1]. Based on the age of onset of the disease, $\mathrm{AD}$ can be divided into early-onset $\mathrm{AD}$ (EOAD) and late-onset $\mathrm{AD}$ (LOAD). EOAD, also known as familial AD, is an autosomal dominant disorder with onset before the 
age of 65 years, and it accounts for approximately $5 \%$ of all AD cases [2,3]. Most cases of EOAD are caused by mutations in the amyloid precursor protein (APP), presenilin 1 (PSEN1), and presenilin 2 (PSEN2) genes [4-6]. LOAD, also known as sporadic AD, accounts for most AD cases. Evidence from a twin study showed that the heritability for AD was 60-80\% [7]. Genome-wide association studies (GWAS) identified susceptibility loci for LOAD, including the apolipoprotein E (APOE) gene, as well as the clusterin $(C L U)$, phosphatidylinositol-binding clathrin assembly protein (PICALM), complement receptor 1 (CR1), bridging integrator 1 (BIN1), sortilin-related receptor L (SORL1), and translocase of outer mitochondrial membrane 40 (TOMM40) genes [8-11]. These genes may affect the risk of LOAD through different pathways, such as cholesterol metabolism, immune system function, and endocytic processes [12]. Among them, the APOE gene is the strongest risk factor for LOAD.

Based on the $A P O E$ gene-related research over the last decade, we conducted a brief review focused on the influence of genetic factors, including the APOE gene, the interaction between the $A P O E$ gene and other genes, and polygenic risk factors for AD development, cognition, brain structure, and function (Figure 1).

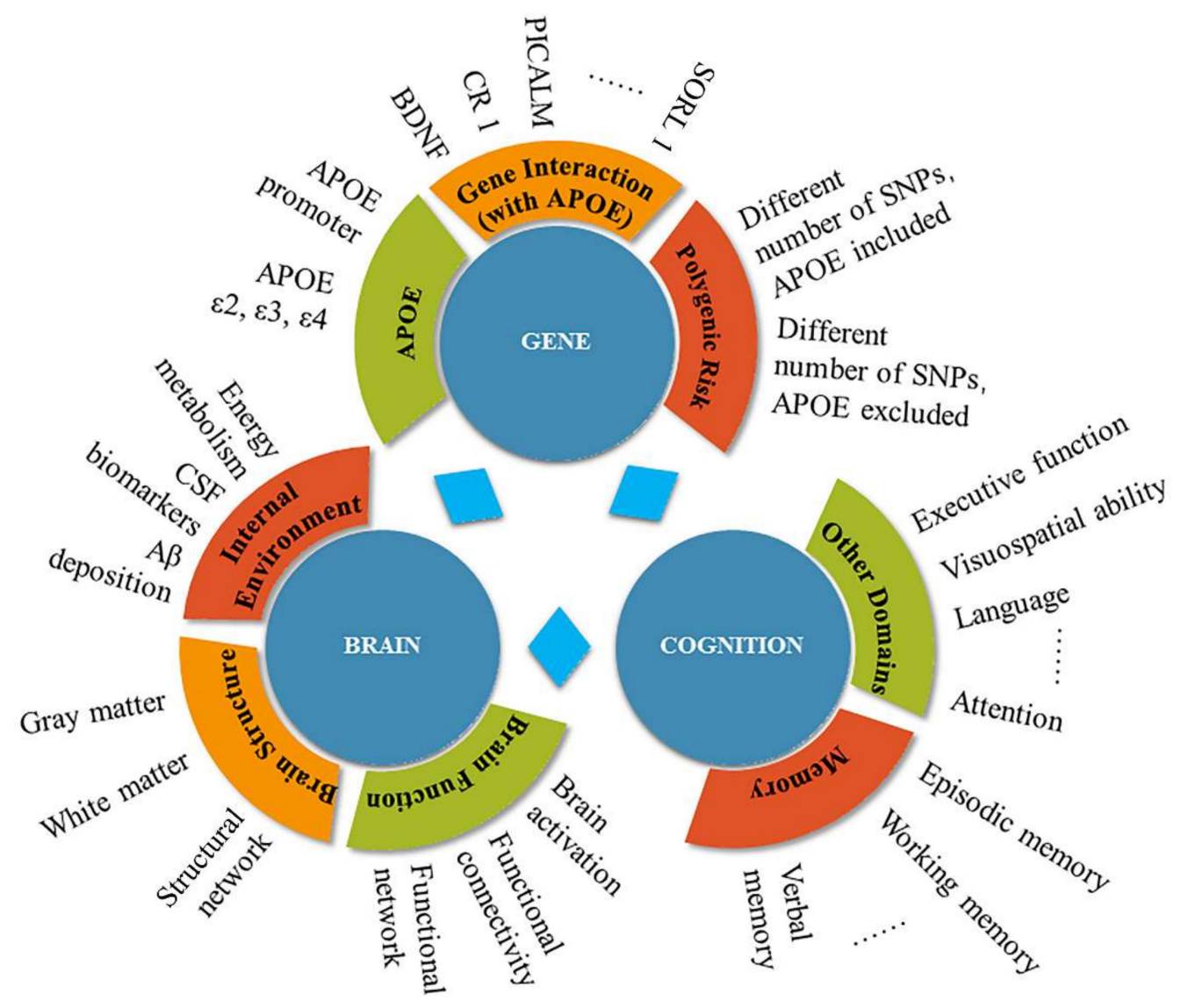

Figure 1. An overview of the gene, brain, and cognition facets of the current review.

\subsection{APOE: Risk Factor for $A D$}

The APOE gene is located on chromosome 19q13.2 with a total of 3597 bases with four exons and three introns, and the gene has three major alleles $(\varepsilon 2, \varepsilon 3$, and $\varepsilon 4)$. The $\varepsilon 3$ allele is the most frequently occurring allele, constituting $60-90 \%$ of the allelic variation, while the frequencies of $\varepsilon 2$ and $\varepsilon 4$ are $0-20 \%$ and 10-20\%, respectively [13-15]. Genetic variation at the APOE locus induces three common isoforms: APOE2 (Cys112, Cys158), APOE3 (Cys112, Arg158), and APOE4 (Arg112, Arg158) which are coded by the $\varepsilon 2, \varepsilon 3$, and $\varepsilon 4$ alleles, respectively (Figure 2) [14,16]. APOE $\varepsilon 4$ is an acknowledged genetic risk for AD [12]. A meta-analysis demonstrated that, for APOE $\varepsilon 4$ carriers, prevalence of $\mathrm{AD}$ was $48.7 \%$, and homozygote prevalence was $9.6 \%$. There are also differences across 
regions/ethnic groups, with the lowest $\varepsilon 4$ carrier prevalence observed in Asia (41.9\%) and southern Europe (40.9\%), while northern Europe has the highest prevalence of $\varepsilon 4$ carriers (61.3\%) [17]. Each copy of the $\varepsilon 4$ allele increases the risk of $\mathrm{AD}$ by approximately threefold, and two copies increase the risk of $\mathrm{AD}$ by $8-14$-fold compared to the $\varepsilon 3 / \varepsilon 3$ genotype. Conversely, the $A P O E \varepsilon 2$ allele has a protective effect. The risk of AD of $\varepsilon 2$ allele carriers is only 0.6 that of the $\varepsilon 3 / \varepsilon 3$ genotype [18-21]. Additionally, the age of onset of $\mathrm{AD}$ is also influenced by the number of APOE $\varepsilon 4$ alleles and decreases by approximately $3-4$ years for every $\varepsilon 4$ allele carried $[18,19]$. Mild cognitive impairment (MCI) is a transitional zone between normal aging and $\mathrm{AD}$, and the annual rate of progression from $\mathrm{MCI}$ to $\mathrm{AD}$ is more rapid than the progression to AD of normal subjects [22]. Meta-analysis also revealed that the $A P O E \& 4$ allele was associated with more than double the risk for progressing from MCI to $\mathrm{AD}$ across studies compared to $\varepsilon 4$ non-carriers [23,24]. Thus, APOE $\varepsilon 4$ is associated with developing AD by increasing the relative risk of $\mathrm{AD}$ and by lowering the age of onset of the disease. Other rare $A P O E$ variations in addition to the three common alleles were also reported $[25,26]$. For example, the $\varepsilon 7$ allele, with two lysine residues replacing glutamic acid at positions 244 and 245 in the carboxyl terminus, is associated with hyperlipidemia and atherosclerosis [27]. Furthermore, since the $\varepsilon 7$ mutant (like $\varepsilon 4$ ) associates preferentially with very low-density lipoproteins, it is also presumed to be related to AD risk. Youn and colleagues investigated the association between APOE $\varepsilon 7$ expression and cognitive impairment, with the results suggesting that $\varepsilon 7$ could serve as a risk factor for cognitive impairment and is particularly associated with vascular disease [28]. However, related research is still limited, and further studies are needed to investigate the role of $\varepsilon 7$ in cognitive impairment and AD.

A

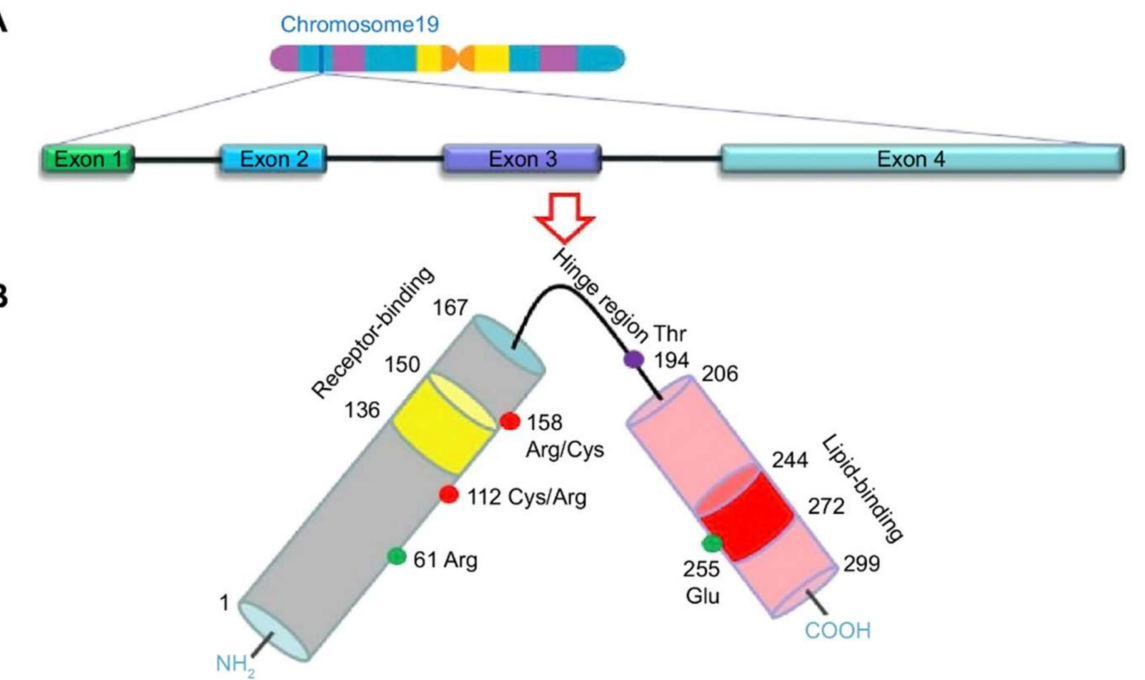

C

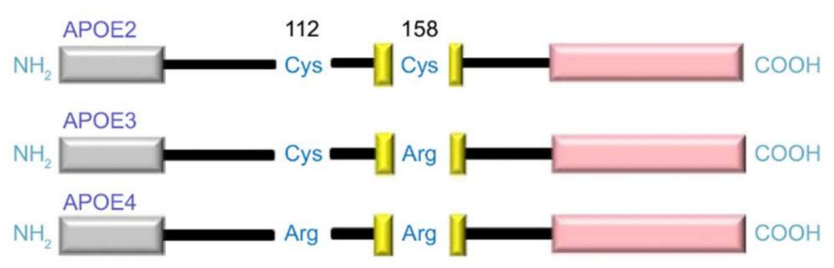

Signaling domain $\square$ Receptor-binding domain $\square$ Lipid-binding domain

Figure 2. Schematic illustration of structural and functional regions of apolipoprotein E (APOE). (A) Location and structure of the APOE gene on chromosome 19. (B) APOE protein. (C) Three major APOE isoforms. (adapted from Reference [16]).

In addition to polymorphisms within the coding region, the polymorphisms within the APOE promoter region are also related to AD risk [29]. These polymorphisms are proposed to modulate the transcriptional activity of the APOE coding region [30]. Three single-nucleotide polymorphisms (SNPs) 
(491A/T, rs449647; 427T/C, rs769446; 219T/G, rs405509) within this region were identified [31]. Xin and colleagues conducted a meta-analysis of 40 studies with 9662 cases and 9696 controls, and revealed that the rs449647 polymorphism and rs405509 polymorphism showed a modest but significant association with AD susceptibility, identifying rs449647 AA and rs405509 TT as risk factors. However, the association between the rs769446 polymorphism and the risk of AD is not consistent, as a significant association was not identified in this meta-analysis [32]. Nonetheless, a recent meta-analysis of 23 publications that included 5703 AD patients and 5692 controls revealed that the $C$ allele of rs769446 was significantly associated with an increase in the risk of $A D$, while there was no association between the rs 449647 or rs 405509 polymorphisms and the risk of AD [33]. The two meta-analyses included 13 overlapping studies. The reasons for these heterogeneous conclusions may include differences among study designs, including the studied populations, sample selection (e.g., age of onset, diagnosis criteria), sample size, methods, and interactions with other risk factors, especially $A P O E \& 4$ status. Thus, the relationship between $A P O E$ promoter polymorphisms and the risk for $\mathrm{AD}$ may differ across studies, and represents a complex pattern with the APOE genotype. Future studies including large samples and different ethnicities should be conducted.

\section{The Effects of the APOE Gene on Cognitive Function and Dementia}

\subsection{APOE \&4 Allele}

Negative effects associated with this gene on cognition are also found in $A P O E \varepsilon 4$ carriers. Compared to non-carriers, $A P O E \varepsilon 4$ carriers exhibit worse cognitive performance and accelerated cognitive decline in healthy, MCI, and AD subjects [34-36].

As memory deficits are considered the major cognitive impairment in AD [37], the relationship between memory decline and the presence of the APOE $\varepsilon 4$ allele in AD was examined a lot. Van der Vlies and colleagues investigated the relationship between the APOE $\varepsilon 4$ allele and cognitive function in $229 \mathrm{AD}$ patients, and the results indicated that memory was more impaired in $\varepsilon 4$ carriers than in non-carriers, suggesting that the APOE genotype may modify the clinical phenotype of AD [38]. Similar results were also found in a study including $523 \mathrm{AD}$ patients that evaluated memory performance based on standard tests and daily function, and found a strong relationship between amnestic presentation and the parameters of increased age of onset, family history, and the presence of the $A P O E \& 4$ allele [39]. Wolk and Dickerson investigated a broad range of cognitive functions, including verbal memory, working memory, executive function, and verbal ability, and they found that the $\varepsilon 4$ carriers exhibited decreased verbal memory and increased medial temporal lobe (MTL) atrophy compared with the non-carriers who exhibited poor working memory, executive function, and verbal ability, as well as increased frontoparietal atrophy [40]. Similar results were also found by Kim and colleagues when examining the impact of the APOE $\varepsilon 4$ allele in AD patients of different ages. AD patients under 75 years of age who did not carry the APOE $\varepsilon 4$ allele or who were heterozygotic showed poor performance in language, visuospatial, and frontal functional tests, while homozygotes older than 75 exhibited worse memory. The cortical atrophy pattern was also different across genotypes and age groups [41]. A longitudinal study also indicated that the $\varepsilon 4$ allele predicted a faster cognitive decline than other alleles, with gene dose-dependent effects observed in mild AD [42] and more evident in younger $\mathrm{AD}$ patients than in older $\mathrm{AD}$ patients [43]. Taken together, these results suggest that $\mathrm{AD}$ patients who are $\varepsilon 4$ allele carriers and non-carriers may suffer from different patterns of cognitive dysfunction, in which age may play an important role.

Farlow and colleagues investigated the impact of the APOE genotype on $\mathrm{MCI}$ in 494 participants, and they found that the presence of the APOE $\varepsilon 4$ allele decreased global cognition and memory performance, seemingly resembling the cognition and memory of patients in the early stages of $\mathrm{AD}$ [34]. Another study also found an association between the APOE $\varepsilon 4$ allele and impaired memory function in both middle-aged and elderly MCI subjects [44]. Furthermore, longitudinal studies revealed that the $A P O E \varepsilon 4$ genotype is predictive of an increased decline in general cognition in $\mathrm{MCI}$, as the 
$\varepsilon 4$ carriers had a significantly more rapid decline [45] in addition to a higher conversion rate to AD, as mentioned above $[23,24]$.

Similar to MCI or AD, the negative effects associated with this gene are also found in cognitively healthy $A P O E \varepsilon 4$ carriers. Although some studies indicated null negative effects [46,47], many studies indicated that, compared to non- $\varepsilon 4$ carriers, $\varepsilon 4$ carriers exhibit worse performance in a range of cognitive functions [36,48] at old age, especially in episodic memory [49-52], executive function [50,52-54], and global cognition [52,55]. In addition to cognitive status, APOE $\varepsilon 4$ is also related to accelerated cognitive decline in old adults, particularly in memory [36]. Caselli and colleagues investigated the $A P O E \varepsilon 4$ effect on memory decline in cognitively normal subjects aged between 21 and 97 years. After approximately five years of follow-up, they found that the $\varepsilon 4$ carriers exhibited memory decline beginning before the sixth decade of life and that memory declined more rapidly than in non-carriers [56]. Homozygous subjects had the most rapid memory decline, indicating that the $A P O E \varepsilon 4$ effect on cognitive decline may be dependent on gene dose [56,57]. Similar results were found in studies with different follow-up times and subjects of different ages [58,59]. Additionally, studies across ethnic groups and regions also confirmed the negative effect of the $\varepsilon 4$ allele. Barnes and colleagues found that $A P O E \varepsilon 4$ is related to a more rapid rate of decline in episodic memory in blacks, similar to the effect of this allele in whites [60]. Another study also found a significant $\varepsilon 4$ effect on the incidence of $\mathrm{AD}$ and on the cognitive decline in Yoruba and African Americans in a large longitudinal comparative study [61]. Lipnicki et al. conducted a longitudinal study of 14 cohorts from 12 countries to investigate the relationship between cognitive decline and the $A P O E$ gene, with a follow-up duration of 2-15 years. They found that $\varepsilon 4$ allele carriers exhibited a slightly more rapid decline in cognitive function, including memory, processing speed, and language than non-carriers [62].

Although some studies did not find significant results, the detrimental effects of the APOE $\varepsilon 4$ allele on cognitive function were confirmed. In addition, memory is commonly affected by the $\varepsilon 4$ allele with gene dose-dependent effects in $\mathrm{AD}, \mathrm{MCI}$, and cognitively healthy subjects. The inconsistent null pattern in some studies may derive from methodological issues, including differences in age, cognitive measures, sample size, and other cognitive risk factors [36,48]. It is noteworthy that the differential effects of $A P O E \varepsilon 4$ on cognition during different life stages represents an example of antagonistic pleiotropy [63]: a reduced or null negative effect is observed in middle age [50,64]; a reversed positive effect is observed in young adults [49]; and the effect size in the elderly is also affected by age [48]. Thus, any APOE-related study must take into account the interaction between age and the APOE gene.

\subsection{Promoter Polymorphisms of the APOE Gene}

In addition to the risk for $\mathrm{AD}$, polymorphisms in the $A P O E$ gene promoter also affect cognition in the aged. Shu and her colleagues included 837 non-dementia elderly subjects living in the community and found that participants with the rs405509 TT genotype showed worse general cognitive function, attention, and executive function than the $\mathrm{G}$ allele carriers, regardless of APOE $\varepsilon 4$ state [65]. Similarly, Chang et al. also confirmed that the rs405509 TT genotype is significantly associated with poor general cognitive function, episodic memory, and executive function. After controlling for the APOE $\varepsilon 4$ genotype, the TT genotype also had a significant age-related decline in global cognition, memory, processing speed, and executive function [66]. Poor language performance in the rs405509 TT genotype was also found in elderly subjects without dementia, and the TT genotype exhibited a more rapid rate of decline in global cognition [67]. Ma and colleagues investigated the interaction effect of the rs405509 $\mathrm{T}$ allele and the APOE $\varepsilon 4$ allele on cognitive ability in Chinese participants, and found significant interaction effects between rs405509 and APOE on general cognition, memory, and attention. The double homozygous genotype ( $\mathrm{rs} 405509 \mathrm{TT} / \varepsilon 4 \varepsilon 4$ ) exhibited a significant reduction in general cognition, memory, and attention [68]. However, in a recent study that included elderly men from Finland, researchers found that the rs405509 TT genotype was significantly associated with improved general cognition, language, arithmetic, and visual spatial ability, independent of the APOE major isoforms [69]. This likely indicates that the effects of rs405509 are different among different ethnicities. 
In addition, the researchers found that subjects with the CC genotype of rs440446 showed better visual spatial ability than subjects with the GG genotype. These studies suggested that the promoter of $A P O E$ can significantly affect cognitive function, but only a few studies were performed, and most of these studies focused on rs405509. Further studies including multiple promoters may increase the understanding of the effect of $A P O E$ on cognition.

\subsection{Genetic Association with the APOE Gene}

Although the $A P O E$ gene explains a part of the genetic risks associated with $\mathrm{AD}$, other genes may still modify the $A P O E \varepsilon 4$ effect [70]. Previous APOE-related studies also investigated the effects of associations between $A P O E$ and other gene polymorphisms on cognition and dementia (Table 1).

Ward and colleagues compared cognitive function in 433 older adults to determine the association between $A P O E$ and brain-derived neurotrophic factor (BDNF Val66Met) polymorphisms. They found a significant $A P O E \times B D N F$ interaction in episodic memory, with $A P O E \varepsilon 2$ carriers displaying episodic memory superior only in $B D N F$ Met carriers [71]. Episodic memory was also found to be impaired in a sample of $A P O E$ \&4-carrying MCI/AD subjects who were also carriers of the Met mutation of BDNF compared to those who Val/Val homozygotes for BDNF [72]. When exploring the synergistic effects of $B D N F, A P O E$, and $\mathrm{HbA1c}$ (glycated hemoglobin) on cognitive decline over 10 years in adults without dementia, Persson et al. found joint effects on memory decline in $B D N F \times A P O E \times$ age, with the subjects carrying the Met allele, as well as at least one copy of the APOE $\varepsilon 4$ allele, showing magnified effect sizes with increasing age on memory decline, while the homozygote Val subjects carrying the $\varepsilon 4$ allele showed a decreased slope [73]. APOE and BDNF may impact cognition together through their interactional effect, but this effect is impacted by education because neither APOE nor BDNF modify the beneficial effects of a university-based educational intervention on cognitive function [74].

Martinez and colleagues examined the synergistic effects of the catechol-O-methyltransferase (COMT rs4680) gene and APOE in $\mathrm{AD}$ and MCI subjects. Although neither COMT alleles nor genotypes were independent risk factors for $\mathrm{AD}$ or $\mathrm{MCI}$, the high-activity genotypes increased the risk of $\mathrm{AD}$ in $\varepsilon 4$ carriers and exhibited a synergistic interaction with the APOE allele. COMT heterozygotes who carry the $\varepsilon 4$ allele exhibited a higher risk for MCI [70]. This study is in accordance with findings by Wang et al., in which the subjects with the COMT high-activity genotypes had an increased risk of developing $\mathrm{AD}$ with the presence of at least one $\varepsilon 4$ allele [75]. Additionally, the combined COMT and $B D N F$ risk is also associated with poor executive function in $\varepsilon 4$ carriers without dementia [76].

The TOMM40 gene shows a linkage disequilibrium pattern with APOE and is associated with the development of AD [77]. Longer poly-T tracts at TOMM40 rs10524523 ('523) are significantly correlated with earlier age of onset of LOAD in APOE $\varepsilon 3$ carriers [78,79]. Johnson and colleagues investigated the relationship between TOMM40'523 and cognitive function in 117 APOE $\varepsilon 3$ homozygous adults, and found that those who were homozygous for very long (VL) poly-T lengths had poorer memory than those who were homozygous for short (S) poly-T length [80]. However, another study also found that the S/S poly-T genotype with APOE e3/3 homozygosity was related to more rapid declines in global cognition and memory in community-based older persons [81]. Thus, the effect of TOMM 40 on cognition and whether there are additive effects between APOE and TOMM40 require further investigation.

The effect of the APOE gene on cognition and dementia is also modified by other genetic factors, including the SORL1 [82], PICALM [83,84], CR1 [83,85], ABCA7 [86], TREM2 [87,88], and BIN1 [83,84], showing complex gene-gene effects. Thus, combining multiple genes and investigating their joint effects is a logical experimental design and may help clarify these complex genetic processes.

\subsection{Polygenic Risk Factors for Cognitive Decline}

As cognition and $\mathrm{AD}$ are highly heritable polygenic traits in humans, investigating polygenic effects on phenotypes is also very important. Therefore, researchers tend to integrate different genetic loci to construct polygenic risk scores (PGS). Studies confirmed that polygenic genetic risk increases 
the incidence of $\mathrm{AD}$ [89], increases the conversion rate of $\mathrm{MCI}$ to $\mathrm{AD}$ [90], and increases the risk of cognitive decline [91-93].

A study of older adults in Belgium showed that weighted PGSs consisting of 22 SNPs (including $A P O E \varepsilon 4$ ) increased the incidence of AD 2.32-fold, and the age of onset of AD decreased by 2.39 years per unit increase in risk score [89]. Another study in the Han Chinese population also found PGSs based on three SNPs were associated with AD risk independent of APOE genotype, and PGSs based on AD risk-associated SNPs may supplement APOE for better assessing individual risk for AD [94]. Marden and colleagues also found that the PGSs based on ten polymorphisms confirmed to predict $\mathrm{AD}$ can predict dementia risk among both non-Hispanic whites and blacks [92]. Lee and colleagues generated AD risk prediction models using a combination of the top-ranked SNPs associated with AD in a Korean elderly sample; when considering age effect, their models were able to predict the onset of $\mathrm{AD}$ in an independent Japanese AD sample, suggesting the potential practical clinical use of combining age and polygenic risk score in predicting $\mathrm{AD}$ [95]. Therefore, the association of polygenic risk score and the incidence of AD was confirmed in different ethnic groups. In addition, increased polygenic risk score can also increase the conversion rate of MCI to AD. A study that included eight risk SNPs (APOE excluded) found that, when an individual carried six or more risk alleles, the conversion rate of $\mathrm{MCI}$ to AD increased twofold [90]. Another European multicenter study found that weighted PGSs constructed with nine AD risk SNPs were significantly associated with the conversion of MCI to AD in $A P O E \varepsilon 4$ allele carriers [96]. A study of MCI patients also found that weighted PGSs calculated with 18 non- $A P O E$ AD risk variants were significantly associated with a decline in general cognition [97].

Verhaaren and colleagues included 5171 middle-aged and older people without dementia to investigate the association of weighted PGSs constructed with $12 \mathrm{AD}$ risk SNPs (including APOE $\varepsilon 4$ ) with general cognition, memory, and possessing speed. A significant correlation between PGS and memory was found, and this association was attenuated when the APOE $\varepsilon 4$ allele was excluded [91]. Similar results were also found in an Australian study on non-demented elderly, and the study found that the weighted PGSs using 12 risk SNPs (including APOE) were related to episodic memory [98]. Marden and colleagues included non-Hispanic white and black participants and examined the efficacy of weighted PGSs constructed by 10 AD risk SNPs (including APOE) in predicting AD and memory performance. The study found that PGSs were associated with a risk of dementia among whites and blacks, whereas the association between PGS and poor memory performance was only found in whites [92]. Similar results were also found in a longitudinal study. In 2016, researchers included a total of 8253 non-Hispanic white and black participants and examined the interaction of weighted PGSs constructed by $22 \mathrm{AD}$ risk SNPs (including $A P O E$ ) and age to predict memory decline. The study found that PGSs with the APOE $\varepsilon 4$ allele and PGSs without the APOE $\varepsilon 4$ allele in whites both can predict a more rapid decline in memory, whereas only PGSs with the APOE $\varepsilon 4$ allele in blacks can predict a faster decline in memory, indicating the genetic efficacy of $A P O E$ in different ethnic groups [93]. Carrasquillo et al. also found that PGSs including the APOE $\varepsilon 4$ allele were associated with memory decline and the progression to MCI/AD in a Caucasian cohort [99]. PGSs are an appropriate method to integrate multiple genetic risk factors. As PGS is an emerging method, the number of studies is also limited. Future related studies may help deepen our understanding of genetic effects on cognitive function and dementia.

\section{The Effects of the APOE Gene on Brain Function}

\subsection{APOE \&4 Allele}

The $\beta$-amyloid $(A \beta)$ hypothesis is the most accepted pathological theory of $A D$, and it is believed that $A \beta$ deposition causes a series of subsequent pathological changes, including the emergence of $\mathrm{p}$-tau and the increase in neurofibrillary tangles in the brain. A number of previous reviews summarized a significant correlation between APOE $\varepsilon 4$ and amyloid load in the brain $[2,100,101]$. We overviewed the articles investigating the influence of $A P O E \varepsilon 4$ on brain amyloid deposition 
published in the last decade, and this conclusion is well proven. Pittsburgh Compound-B (PiB) uptake in the temporoparietal and frontal cortices of patients with $\mathrm{AD}$ is positively correlated with $\varepsilon 4$, and both the distribution and the annual increase in $A \beta$ deposition exhibited a gene dose-dependent effect $[102,103]$. The same relationship is observed in patients with MCI and in cognitively healthy elderly subjects; those who carry $\varepsilon 4$ have more deposition than non-carriers [104,105]. In fact, a meta-analysis summarized by Jansen and colleagues revealed $A \beta$ deposition onset early in the fourth decade of life of $\varepsilon 4$ carriers, and they had $A \beta$ deposition levels that were two to three times higher than that of non-carriers [101]. APOE $\varepsilon 4$ also reduced the age that $\mathrm{A} \beta$ was detected; $\mathrm{A} \beta$ positivity occurs in normal subjects at approximately 56 years of age and in non-carriers at approximately 76 years of age [106]. A significant $A P O E \times$ age interaction was also observed by Gonneaud and colleagues. $\mathrm{A} \beta$ deposition increased nonlinearly with age in APOE $\varepsilon 4$ carriers but not in non-carriers in their study [107]. Moreover, it seems that the association between $A \beta$ deposition and cognitive performance is modified by APOE status. One study reported that higher amyloid content was predictive of a longitudinal decline in executive function and memory tests in $\varepsilon 4$ non-carriers [108]; however, another study reported severe cognitive impairment in addition to higher $A \beta$ deposition in $\varepsilon 4$ carriers [109]. This discrepancy may result from the difference of age in the two groups (62 years old in the first study and 80 years old in the latter one). Furthermore, there was also a report that increased cognitive activity over a lifetime can diminish cortical PiB retention in $\varepsilon 4$ carriers [110], which makes the relationship among $A P O E$, cognition, and $\mathrm{A} \beta$ deposition quite interesting and worthy of further study.

Corresponding to the influence of $\varepsilon 4$ on $A \beta$ deposition, a study also showed that the decrease in $A \beta_{42}$ and the increase in tau/p-tau in the cerebrospinal fluid (CSF) were related to $\varepsilon 4$. Liu and colleagues observed 1718 participants from Alzheimer's Disease Neuroimaging Initiative (ADNI) and found significantly decreased $A \beta_{42}$ and increased tau/p-tau levels in the CSF in the $\varepsilon 4$ carriers, which appeared earlier than other biomarkers of $\mathrm{AD}$ [111]. This effect is gene dose-dependent; homozygosity for the $A P O E \varepsilon 4$ allele results in a worse phenotype than both heterozygosity and lack of the APOE $\varepsilon 4$ allele. The influence of $\varepsilon 4$ on CSF biomarkers was even stronger than the clinical status $[112,113]$. However, the association between tau and the APOE genotype is not observed in people without $A \beta[114,115]$. Considering the negative correlation between $A \beta$ deposition in the brain and $A \beta_{42}$ in the CSF, as well as the influence of $A \beta$ deposition on the change in tau/p-tau, this relationship between $\varepsilon 4$ and the CSF biomarkers is understandable. However, there are negative results that should arouse our attention at the same time. For example, a study including samples from Sweden, Finland, and Germany found that the change in CSF $A \beta_{42}$ was independent of the APOE genotype in some of their sub-cohort. They also found that $\varepsilon 4$ may not have a direct effect on CSF levels of $A \beta_{42}$, but did demonstrate $A P O E \varepsilon$ 4-associated preclinical pathology in the elderly [116]. For this reason, the effect of $\varepsilon 4$ on CSF $A \beta_{42}$ may not exist in some younger sample populations because they do not have amyloid.

As one of the earliest biomarkers of $\mathrm{AD}$, glucose hypometabolism is also affected by the APOE genotype. Dozens of studies observed that preclinical $\varepsilon 4$ carriers have glucose hypometabolism in regions similar to the change in glucose patterns in AD [117], including regions in the parietal, temporal, and prefrontal areas, with the posterior cingulate cortex (PCC) representing the most significant region [118]. This association could be observed in cognitively normal individuals as early as 30 years of age [119]. As a risk factor, an increase in the number of $\varepsilon 4$ alleles will result in worse glucose metabolism with increasing age, and this gene dose effect may be more severe in women [120]. A few researchers reviewed articles on APOE $\varepsilon 4$ and metabolism, suggesting that the dysfunction of many brain parameters related to metabolism may reflect an inherent dysregulation of glucose metabolism in $\varepsilon 4$ carriers [121]. For instance, Zhao et al. reported that $\varepsilon 4$ may impair cerebral insulin signaling, which could partly explain the way $\varepsilon 4$ affects glucose metabolism [122]. Moreover, the association between $\varepsilon 4$ and the reduced mitochondrial cytochrome oxidase activity observed in the PCC may also contribute to this abnormal energy metabolism in the brain [123].

$A P O E$ can also influence brain structure to a certain extent, including the atrophy of the hippocampus, amygdala, entorhinal cortex, and total brain volume. Additionally, increases 
in white-matter hyperintensity volumes are often reported in many studies [124]. Among the gray-matter atrophy associated with $\varepsilon 4$, the hippocampal region was the most frequently mentioned. A meta-analysis conducted by Liu and colleagues found a statistically significant association between the $\varepsilon 4$ allele and hippocampal atrophy in six cross-sectional studies that included both healthy elderly subjects and MCI/AD subjects [100]. They further confirmed this association between $\varepsilon 4$ and hippocampal atrophy in late MCI and AD patients, with a gene dose effect even shown in the late MCI patients [111]. Other studies also reported that increasing $\varepsilon 4$ gene dose caused hippocampal atrophy $[125,126]$. Atrophy is not restricted to the hippocampus. A previous study also found an association of the $\varepsilon 4$ allele with increased susceptibility of the temporal cortex and decreased vulnerability in the frontoparietal neocortical regions in AD patients [127-129]. However, at the same time, many studies showed that $\varepsilon 4$ and gray-matter atrophy were not always closely related. Several studies compared the gray-matter volume of $\varepsilon 4$ carriers and non-carriers and found no difference $[130,131]$, especially in young children and elderly with advanced age [132,133]. This phenomenon makes researchers suggest that the effect of $\varepsilon 4$ may not be detectable when the subjects are young, and, in old age, the shrinkage caused by age may mask the effect of $\varepsilon 4$ [124]. The effect of $\varepsilon 4$ on brain structure may also be an example of antagonistic pleiotropy. However, considering that reports also showed negative results in middle-aged adults [134], another suggestion is that the atrophy influenced by $\varepsilon 4$ may only occur more proximal to the onset of clinical symptoms of dementia [133], which is in agreement with the close relationship between $\varepsilon 4$ and AD. The study of white matter is very similar to that of gray matter, and both positive and negative results were reported. The area impaired by $\varepsilon 4$ was mainly centered in regions around the medial temporal lobe, with decreased white-matter fractional anisotropy (FA) in the left parahippocampal gyrus [135], limbic, and medial temporal regions [136], decreased mean diffusivity (MD) in the corona radiate and corpus callosum, and decreased axial diffusivity (AD) in the genu of corpus callosum [137]. Since APOE has effects on the brain vascular system [121], it may be one of the $\varepsilon 4$-mediated pathways that impairs white matter, and some cerebrovascular diseases could accompany these effects [138].

Functional MRI (fMRI) can reflect brain activity both in a resting state and while performing a task. The first fMRI study that investigated gene effects on brain function was conducted by Smith and colleagues in 1999, who reported decreased brain activation during a visual task in $\varepsilon 4$ carriers [139]. Trachtenberg and colleagues reviewed $27 \mathrm{fMRI}$ studies before 2012 and concluded that $\varepsilon 4$ carriers can present both decreased and increased brain activation compared to non-carriers, and the location of change was inconsistent as well. They thought the reasons for these inconsistent findings regarding the direction and location of activation among studies included the different tasks used in the studies, the different family history of AD of the participants, and the age difference [140]. The $\varepsilon 4$ carriers exhibited damaged connectivity between the precuneus and several regions during a memory encoding task [141], but recruited more regions in low load and displayed fewer increases in activation in high load in an n-back working task [142]. Old age was associated with increased activity in $\varepsilon 4$ carriers in a face-name task [143]. Brain activity is susceptible to many factors during task fMRI; it is quite difficult to identify a consistent pattern; however, with an increasing number of resting state studies in recent years, the functional connectivity (FC) related to certain areas is more consistently affected. The default mode network (DMN) was the most affected network; both decreased FC inside the DMN [144] and decreased FC between the DMN and other networks [145] were found in different studies. FC alterations between the hippocampus or parahippocampal region and other brain regions were also frequently reported [146-149]. At the same time, there are still other areas with both increased and decreased FC characteristics reported in the literature [150-152]. Although we excluded the effect of task paradigm in resting fMRI, the differences in age, disease stage, and sex were still easily unified in different research samples. 


\subsection{Promoter Polymorphisms of the APOE Gene}

In addition to the impacts on cognitive function and risk for AD mentioned above, polymorphisms in the promoter region of the APOE gene influence brain structure and function. Lambert and colleagues measured the $\mathrm{A} \beta$ load in Brodman areas 8 and 9 in $74 \mathrm{AD}$ patients with different promoter polymorphisms. Both rs449647 AA carriers and rs405509 TT carriers showed a significant increase in the $\mathrm{A} \beta$ load of APOE $\varepsilon 4$ non-carriers compared to that of carriers [153]. Another study in elderly people without dementia also found that the rs449647 AA carriers had significantly increased A $\beta$ deposition [154]. However, at the same time, it is noteworthy that there is study a reporting conflicting results, which showed that the severity of cerebral amyloid angiopathy was not affected by rs449647 and rs405509 genotype [155]. Our recent work systematically studied the impact of rs405509 on brain structure and function. We observed that there was a significant interaction between rs 405509 and $A P O E$ on general mental status in a sample of 836 community-based elderly people, and a significant interaction between rs405509 and APOE on the right inferior temporal gyrus and right fusiform gyrus in 102 people who had an MRI scan. The carriers of both $\varepsilon 4$ and rs405509 T had the smallest gray-matter volume [68]. The interaction between rs405509 and age was also demonstrated in 120 people without dementia. The carriers of the rs405509 TT genotype showed a steeper decline with aging than the $\mathrm{G}$ carriers, and the cortical thickness covariance between several brain regions was also modulated by the interaction of the rs 405509 genotype and age [67]. The same interaction effect was observed in the white-matter network; the rs405509 TT carriers had reduced global and local efficiency, mainly in the left anterior and posterior cingulate cortices [65], and decreased network betweenness centrality in the left inferior frontal gyrus pars opercularis, the left posterior cingulate cortex, the right inferior occipital gyrus, and the left angular gyrus [66]. Additionally, resting-state fMRI revealed that rs405509 also significantly interacted with APOE in the anterior cingulate gyrus, medial frontal region, and precuneus in the anterior and posterior DMN, with both TT and $\varepsilon 4$ carriers mostly impairing the DMN [156]. The results listed above suggest that the promoter of APOE can significantly affect the structure and function of the brain. However, only a few studies related to APOE were performed, which limits our understanding of its importance. 
Table 1. Studies of genetic association with the apolipoprotein $\mathrm{E}(A P O E)$ gene.

\begin{tabular}{|c|c|c|c|c|}
\hline Study & Participants & Genes & Interaction Impact on Disease & Possible Mechanisms Described by the Authors \\
\hline $\begin{array}{l}\text { Martinez et al., } \\
2009[70]\end{array}$ & $223 \mathrm{MCI}$ patients, $345 \mathrm{AD}$ and $253 \mathrm{HC}$ & COMT & $\begin{array}{c}\text { COMT (Val158 Met) polymorphism is not an independent risk } \\
\text { factor for AD or MCI, but shows a synergistic effect with } A P O E \\
\varepsilon 4 \text { allele that proves greater in women with AD. }\end{array}$ & Lowering the estrogen levels of brain. \\
\hline $\begin{array}{l}\text { Wang et al., } \\
2005[75]\end{array}$ & $66 \mathrm{AD}$ and $86 \mathrm{HC}$ & COMT & $\begin{array}{l}\text { The COMT high-activity genotypes and APOE } \varepsilon \text { allele had a } \\
\text { synergistic effect on the risk of AD. }\end{array}$ & $\begin{array}{l}\text { A high metabolism of estrogen by } C O M T \text { may have } \\
\text { reduced the protective effect of estrogen in AD. }\end{array}$ \\
\hline $\begin{array}{l}\text { Sapkota et al., } \\
2017[76]\end{array}$ & 634 non-demented older adults & COMT BDNF & $\begin{array}{c}A P O E \varepsilon 4+\text { carriers with } B D N F \text { Met/Met genotype and increasing } \\
\text { allelic risk in the COMT + BDNF risk panel had poorer executive } \\
\text { function performance. }\end{array}$ & - \\
\hline $\begin{array}{l}\text { Ward et al., } \\
2014 \text { [71] }\end{array}$ & 433 older adults (50-79 years) & $B D N F$ & $\begin{array}{c}\text { In } B D N F \text { Val homozygotes, the cognitive consequences of } A P O E \\
\text { polymorphisms were minimal. However, in } B D N F \text { Met carriers, } \\
\text { the hypothesized beneficial/detrimental effects of } A P O E \\
\text { polymorphisms were found. }\end{array}$ & $\begin{array}{l}\text { Firstly, there is a biological interaction related to the } \\
\text { systems or aging-related roles of the encoded proteins. } \\
\text { Secondly, the additive effects of the polymorphisms } \\
\text { caused the analyses to reach statistical significance. }\end{array}$ \\
\hline $\begin{array}{l}\text { Gomar et al., } \\
2016 \text { [72] }\end{array}$ & $\begin{array}{l}175 \text { healthy subjects and } 222 \text { with } \\
\text { prodromal and established } \mathrm{AD}\end{array}$ & $B D N F$ & $\begin{array}{c}B D N F \text { Met and } A P O E \& 4 \text { carriers had thinner posterior cingulate } \\
\text { and precuneus cortices in healthy subjects, and longitudinal } \\
\text { decline in entorhinal thickness in MCI and AD. }\end{array}$ & - \\
\hline $\begin{array}{l}\text { Persson et al., } \\
2013[73]\end{array}$ & $\begin{array}{l}888 \text { non-demented adults } \\
\text { (35-85 years) }\end{array}$ & $B D N F$ & $\begin{array}{c}\text { A joint effect on memory decline in } B D N F \times A P O E \times \text { age, with } \\
\text { the subjects carrying the Met allele, as well as at least one copy of } \\
\text { the } A P O E \varepsilon 4 \text { allele showing magnified effect sizes with increasing } \\
\text { age on memory decline, while the homozygote Val subjects } \\
\text { carrying the } \varepsilon 4 \text { allele showed a decreased slope. }\end{array}$ & - \\
\hline $\begin{array}{l}\text { Yu et al., } 2007 \\
{[77]}\end{array}$ & $\begin{array}{l}193 \text { late-onset } \mathrm{AD}, 232 \text { subjects with } \\
\text { no cognitive impairment, } \\
\text { and } 125 \text { individuals with other } \\
\text { neurodegenerative disorders }\end{array}$ & TOMM40 & $\begin{array}{l}\text { It showed intriguing linkage disequilibrium with the } \varepsilon 4 \text { allele } \\
\text { and was strongly associated with the risk for developing late } \\
\text { onset AD. }\end{array}$ & - \\
\hline $\begin{array}{l}\text { Roses et al., } \\
2009 \text { [78] }\end{array}$ & $\begin{array}{c}191 \mathrm{AD} \text { and } 131 \mathrm{HC} \text { (mean age: about } \\
75 \text { years) }\end{array}$ & TOMM40 & $\begin{array}{l}\text { Individuals with long poly-T repeats linked to } A P O E \varepsilon 3 \text { develop } \\
\text { late onset } A D \text { on an average of } 7 \text { years earlier than individuals } \\
\text { with shorter poly-T repeats linked to } A P O E \varepsilon 3 \text {. }\end{array}$ & $\begin{array}{l}\text { It is possible that the rs } 10524523 \text { polymorphism, alone } \\
\text { or in conjunction with other single-nucleotide } \\
\text { polymorphisms in TOMM } 40 \text {, acts at a distance to } \\
\text { affect transcription of APOE. }\end{array}$ \\
\hline $\begin{array}{l}\text { Johnson et al., } \\
2011[80]\end{array}$ & $\begin{array}{l}117 \text { healthy APOE } \varepsilon 3 \text { homozygous } \\
\text { adults (mean age: about } 55 \text { years) }\end{array}$ & TOMM40 & $\begin{array}{c}\text { Those who were homozygous for very long poly-T lengths had } \\
\text { poorer memory than those who were homozygous for short } \\
\text { poly-T length in } A P O E \varepsilon 3 / 3 \text {. }\end{array}$ & - \\
\hline $\begin{array}{l}\text { Yu et al., } \\
2017 \text { [81] }\end{array}$ & $\begin{array}{c}1151 \text { old people (mean age: about } \\
78.5 \text { years) }\end{array}$ & TOMM40 & $\begin{array}{l}\text { It revealed an association of } A P O E \varepsilon 3 / 3-T O M M 40^{\prime} 523 \text { haplotypes } \\
\text { with cognitive decline in community-based older persons such } \\
\text { that the } \mathrm{S} / \mathrm{S} \text { poly-T genotype is related to faster cognitive decline, } \\
\text { primarily in the domains of episodic and semantic memory. }\end{array}$ & $\begin{array}{c}\text { The TOMM40 variant is implicated in affecting the } \\
\text { level of neurofilament light proteins in } \\
\text { cerebrospinal fluid. }\end{array}$ \\
\hline $\begin{array}{l}\text { Louwersheimer } \\
\text { et al., 2017 [82] }\end{array}$ & $\begin{array}{l}\text { A family with } 9 \text { AD patients } \\
\text { spanning } 4 \text { generations, with an } \\
\text { inheritance pattern suggestive of } \\
\text { autosomal dominant }\end{array}$ & SORL1 & $\begin{array}{l}\text { All four affected family members carried a rare variant in the } \\
\text { vacuolar protein sorting domain } 10 \text { domain of the SORL1 gene, } \\
\text { associated with } A \beta \text { protein precursor processing and AD risk. }\end{array}$ & $\begin{array}{l}\text { A combination of homozygous or heterozygous } \\
\text { APOE₹4 and dysfunctional SORL1 may lead to } \\
\text { abnormal increases in extracellular A } \beta \text { loads. }\end{array}$ \\
\hline $\begin{array}{l}\text { Barral et al., } \\
2012 \text { [83] }\end{array}$ & $\begin{array}{l}1365 \text { subjects in the National Institute } \\
\text { on Aging Late-Onset Alzheimer's } \\
\text { Disease Family Study }\end{array}$ & $\begin{array}{l}\text { CR1, BIN1, CLU, } \\
\quad \text { PICALM }\end{array}$ & $\begin{array}{l}\text { Several genotype patterns influenced episodic } \\
\text { memory performance. }\end{array}$ & - \\
\hline
\end{tabular}


Table 1. Cont

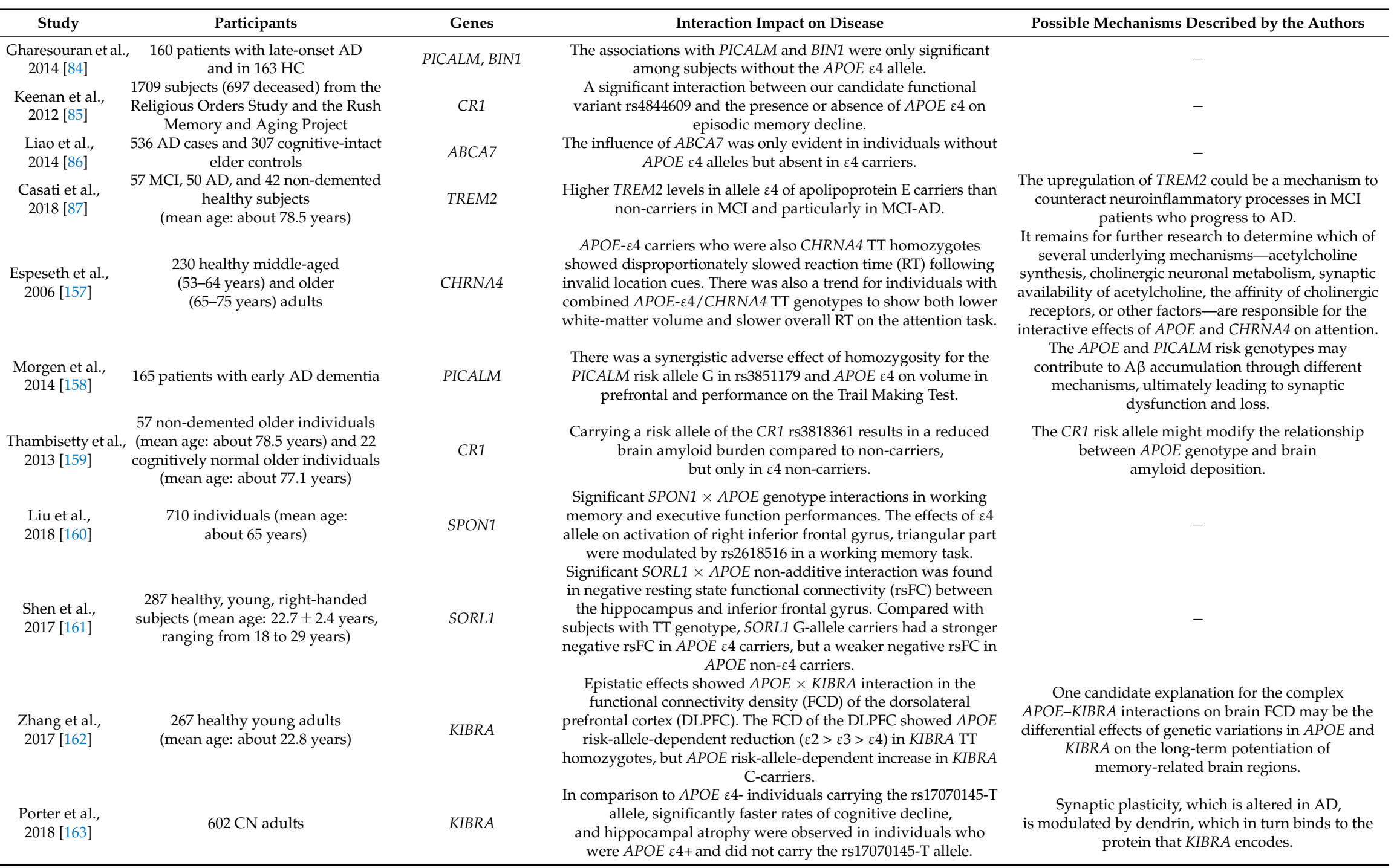

$\mathrm{HC}$, healthy control; $\mathrm{CN}$, cognitive normal; $\mathrm{MCI}$, mild cognitive impairment; $\mathrm{AD}$, Alzheimer's disease. 


\subsection{Genetic Association with the APOE Gene}

Similar to the cognitive function we mentioned above, the interaction between other genes and $A P O E$ can also be demonstrated with neuroimaging (Table 1). Elderly people who carry both CHRNA4 (a nicotinic receptor subunit gene) TT and APOE $\varepsilon 4$ showed slower reaction time and lower white-matter volume in a visuospatial attention task [157]. The risk allele of the PICALM gene in rs3851179 may also interact with $A P O E \varepsilon 4$ to cause gray-matter volume impairment of the prefrontal cortex [158]. Carrying a risk allele of the $C R 1$ rs3818361 results in a reduced brain amyloid burden compared to non-carriers, but only in $\varepsilon 4$ non-carriers; $A P O E \varepsilon 4$ individuals show a significantly increased brain amyloid burden [159]. Liu and colleagues found that the effects of APOE $\varepsilon 4$ on the activation of the triangular part of the right inferior frontal gyrus were modulated by rs2618516 in the spondin 1 (SPON1) gene in a working memory task [160]. Another study reported alterations of FC between the hippocampus and inferior frontal gyrus in a resting-state network in people who carry both the $\mathrm{G}$ allele of the SORL1 gene and the $\varepsilon 4$ allele of APOE [161]. In addition, significant APOE risk-allele-dependent reduction in the brain FC density in the dorsolateral prefrontal cortex can be observed in carriers of the TT allele of the kidney and brain expressed protein (KIBRA) gene, but a significant $A P O E$ risk-allele-dependent increase in the brain FC density was observed in carriers of the $C$ allele of KIBRA [162]. At the same time, people with both APOE $\varepsilon 4$ and KIBRA C were observed to have significant hippocampal atrophy [163]. In addition to the genes we described above, there are still many other genes that have significant interactions with $A P O E$, and their effects on neuroimaging are also worth further exploring. All of these results suggest that different AD risk genes may interact with each other, and this interaction can cause many observable effects on neuroimaging. It is important to consider the interaction between genes when we discuss the influence of innate factors on AD pathology, and the underlying mechanism still needs to be further studied.

\subsection{Polygenic Risk for the Brain}

In recent years, polygenic risk was frequently applied to AD studies because it maximizes the impact of all genetic factors. An increasing number of studies proved that polygenic risk can cause significant changes in brain structure and function.

Sleegers and colleagues found that PGS consisting of 22 SNPs was negatively correlated with the density of $A \beta_{42}$ in the CSF in a sample of elderly people in Belgium [89]. The same negative correlation was also found in a Dutch study with 22 SNPs, coupled with a significant correlation between PGS and the density of tau in the CSF [164]. Louwersheimer and colleagues reported that the density of tau and p-tau in CSF was significantly correlated with PGS consisting of 18 SNPs, not including $A P O E$, in a group of MCI patients [97]. In another study, Voyle and colleagues used case control PGS (APOE excluded) to predict CSF tau and $\mathrm{A} \beta$, and they found it to be more predictive of $\mathrm{A} \beta$ and tau pathologies than the predictors that consisted of age, sex, and APOE genotype, although marginally [165]. This correlation was much stronger in a study of cognitively normal elderly subjects and MCI patients; the PGS consisted of 31 SNPs (APOE excluded) that were strongly associated with CSF A $\beta$, CSF tau, A $\beta$ deposition load, neurofibrillary tangles, and rapid longitudinal clinical progression [166]. However, not all of the results showed a significant correlation. Darst and colleagues found that pathway-specific PGS consisting of genes involved in A $\beta$ clearance, cholesterol metabolism, and immune response cannot provide increased predictive power for CSF A $\beta$, neurodegeneration, and tau pathology after excluding APOE [167]. The inconsistent results among different studies may be because of the different SNPs used in each study and the different sample characteristics, which should be addressed in further studies.

Structural MRI and functional MRI research provided more evidence about the influence of polygenic risk on the brain. Sabuncu and colleagues used PGS consisting of 31 SNPs (including APOE) to investigate the relationship of polygenic risk with cortical thickness in seven AD-specific regions. They found that PGS was significantly correlated with the thickness of these regions, including the entorhinal area and part of the temporoparietal area [168]. Additionally, PGSs consisting of nine SNPs 
related to inflammation or immunity were reported to be significantly correlated with the thickness of the regional cortex in a group of healthy older people [169]. In some specific regions, an association between PGS and precuneus volume was found in a recent study [170]; however, the most frequently reported structural regions that were affected by PGS were the entorhinal cortex and hippocampus. Harrison and colleagues calculated PGS that represented APOE, CLU, PICALM, and family history, and found that both weighted and unweighted PGSs were strongly related to the change in the thickness of the hippocampus and entorhinal cortex [171]. The volume loss in these two regions was also reported in an ADNI study, and the PGS consisted of 31 SNPs in this study [172]. Lupton and colleagues once again highlighted the sensitivity of the hippocampus. They examined the association of the hippocampus and amygdaloid volumes, and the PGS consisted of 19 SNPs that did not include APOE. They found a significant correlation between hippocampus volume and PGS in healthy old people and in MCI patients, but not in healthy young people [173]. However, the effect of PGS on the hippocampal function of healthy young people was found in an fMRI study [174]. The influence of PGS is also reflected with white-matter disruption. Foley and colleagues not only reported lower hippocampal volume with higher PGS, even when excluding the effect of APOE, but also reported that the FA of the right cingulum was inversely correlated with PGS [175]. As of now, the number of neuroimaging studies on PGS risk is still insufficient, especially studies examining white matter and brain functional activity. We expect these future studies to provide a deeper understanding of the pathology of PGS through neuroimaging.

\section{Discussion}

In this review, we examined the effects of genetic factors on AD risk, cognition, and the brain. The $\varepsilon 4$ allele of $A P O E$ not only increases the risk of $\mathrm{AD}$, but also reduces the age of onset of $\mathrm{AD}$. Behavioral studies showed that the $\varepsilon 4$ allele is significantly associated with decreased cognitive performance (especially memory) and with cognitive decline. Imaging studies also showed that $\varepsilon 4$ is associated with changes in the brain internal environment (A $\beta$ deposition, CSF biomarkers, and glucose metabolism), gray-matter atrophy, white-matter damage, brain activation, and brain connectivity. The detrimental effect of the $A P O E \varepsilon 4$ allele in the aged was confirmed. In addition to the $\varepsilon 4$ allele, polymorphisms within the $A P O E$ promoter region are also associated with the risk of $\mathrm{AD}$, cognition, and brain changes. However, there are few related studies, and the promoter region also has a complex effect on the APOE genotype; therefore, further research is needed. In addition, some other genetic factors also interact with the $A P O E$ gene and produce a complex gene-gene effect. Both $\mathrm{AD}$ and individual cognitive function are affected by multiple genes. Considering the complex effects of different genes, PGS seems to be an appropriate method to comprehensively investigate genetic factors. This method was also applied to cognitive and brain research by increasing numbers of researchers. Next, we conduct a simple discussion based on past research and make recommendations for future research.

\subsection{Study Sample}

\subsubsection{Age}

Age is one of the most important factors that can significantly influence the effect of the expression of $A P O E$ and other risk genes. The negative influence of $A P O E \varepsilon 4$ on cognition increases with age [176]. There is evidence demonstrating that $A P O E$ has no association with cognition or AD risk in the young [177] or the oldest old people $[178,179]$. The effects of genetics on neuroimaging are more likely to be observed at specific ages [124]. This may be because the effect of APOE $\varepsilon 4$ may not be detectable when the subjects are young, and, in old age, the impairment caused by age may mask the effect of $A P O E \varepsilon 4$. However, there were also studies reporting a protective effect of $A P O E \varepsilon 4$ on cognition in children and young adults, suggesting that $A P O E \varepsilon 4$ carriers may have superior cognitive performance than non-carriers [180]. An "antagonistic pleiotropy" theory was used to explain this 
phenomenon, which represents a positive effect of a gene in early life but a negative effect of the gene later in life [181]. Superior cognitive performance in the oldest old were also reported, which makes the APOE $\varepsilon 4$ allele seem protective [182]. However, researchers believe that this is due to "selective survivors", and survivors may have a more positive effect in the absence of other AD risk factors or the existence of other protective factors [183]. In addition, the cognitive domain that was significantly affected by $A P O E \varepsilon 4$ differed in age. Kim and colleagues found that language, visuospatial, and frontal function were affected by APOE4 in subjects younger than 75 years, but memory was the most affected function in people older than 75 . Additionally, a genotype $\times$ age interaction was also found in the same study [41]. After controlling for the status of the APOE genotype, the APOE promoter caused a decline in global cognition, memory, processing speed, and executive function, which were effects that were also age-related [66]. The gene dose effect of $A P O E$ improved with increasing age as well [120]. Regarding the causes of this series of phenomena, we believe aging is one of the unavoidable interfering factors. Since aging causes similar cognition and brain impairments, it is important for researchers to distinguish the effects of aging and AD genetic risk factors. Only in this way can the effect of $A P O E$ and other risk genes on the pathology of AD be accurately described.

\subsubsection{Family History}

In the process of summarizing these studies, we found that the differences in family history may also influence the role of the APOE gene in the pathological development of AD. Bloss and colleagues found that, in children, carrying APOE $\varepsilon 4$ had no effect on cognition; however, those children with both $A P O E \& 4$ and a family history had significantly poorer performance on cognitive tests [184]. Increased activation in the hippocampus, posterior cingulate, and temporoparietal regions was also found in older people with both APOE $\varepsilon 4$ and family history [185]. However, the effect was sometimes reversed. In an episodic memory task, $A P O E \varepsilon 4$ carriers without a family history of AD showed increased MTL activation, but those with a family history of AD showed the least activation in the same region [186]. A family history is always strongly linked with genes. The interaction between the $A P O E$ gene and family history may actually be an interaction between genes. Due to the development of polygenic testing, we observed an increasing number of genes that interacted with the APOE gene, such as BDNF [71], COMT [70], and the APOE promoter [68]. However, improved models are still needed to shed more light on the relationship between family history and these risk factors.

\subsubsection{Other Diseases}

The APOE gene is not the only genetic risk factor for $\mathrm{AD}$; also, it is not the only gene associated with AD. Many other neurological disorders were confirmed to be affected by APOE. Compared to non-carriers, $A P O E \varepsilon 4$ carriers with traumatic brain injury had significantly increased A $\beta$ deposition [187], and they may also suffer from poor neurological outcomes [188]. People with both $A P O E \varepsilon 4$ and type 2 diabetes had a significantly higher risk of AD than non-carriers [189]. However, at the same time, diabetes was associated with the non-APOE genotype in an AD patient group [190]. The coexistence of $A P O E \varepsilon 4$ and hypertension was associated with worse cognitive function compared to those with neither or either alone [191]. As exhibited by stroke, vascular dementia, multiple sclerosis, Parkinson's disease, dementia with Lewy bodies, and so on, there are many other neurological disorders that are affected by the $A P O E$ gene or that can interact with the $A P O E$ gene [138]. It is more complicated with polygenes, and these genes may all be closely related to different diseases. Those risk genes involved in cholesterol metabolism, such as CLU, ATP-binding cassette subfamily A member 7 (ABCA7), and SORL1, may also be associated with hyperlipidemia; those risk genes involved in immune response, such as CR1, CD33, MS4A, TREM2, and CLU, may also be associated with diseases related to the immune system [192]. Therefore, the approach to identifying pathways related to the pathogenesis of $\mathrm{AD}$ from complex gene effects is particularly important in $\mathrm{AD}$ research. However, the pathological theory of AD is still controversial, and it is difficult to completely separate some diseases from AD. 


\subsection{Methodological Issue}

\subsubsection{Uniformity}

The very large discrepancy between study sample characteristics makes it particularly difficult to compare the results of different studies. The inclusion and exclusion criteria of participants, the ethnic composition of the research sample, the family history of AD of each subject, and even the sex ratio can make a difference in the results. The neuropsychological tests used in studies were sometimes different; for example, different memory tests could focus on different types of memory or different components of memory, and the reliability and validity may also differ between these tests. These factors make comparisons between studies inconclusive, although they all measure memory function. Another large difference between studies is examining polygenic risk. As we can see from Table 2, the number of SNPs used to estimate the PGSs is quite different; the number could be as low as three in one study [94] to as high as 31 in another study [172]. The criteria for obtaining SNPs are also diverse from each other; they could be defined as specific SNPs [166] or they could be determined by different thresholds [169]. Some genes such as APOE, BIN1, CLU, ABCA7, CR1, PICALM, MS4A, CD33, TMM40, and $C D 2 A P$ were included in the PGSs frequently, but the pathways via which they affect AD deserve further investigation. There was also a difference in whether the APOE gene was included, which could make a large difference in the results. It is difficult to resolve all the differences among studies, but we at least need to be aware of these differences when we attempt to compare the results from different studies. 
Table 2. Studies of polygenic risk on cognition and brain

\begin{tabular}{|c|c|c|c|c|c|c|c|}
\hline Study & Participants & Study Design & SNP & APOE & Conversion Risk & Cognitive Impact & Neuroimaging Impact \\
\hline $\begin{array}{l}\text { Sabuncu et al., } \\
2012[168]\end{array}$ & $\begin{array}{l}104 \mathrm{CN}(75.9 \pm 5.1) \\
\text { and } 100 \mathrm{AD} \\
(75.1 \pm 7.8)\end{array}$ & $\begin{array}{l}\text { Cross-sectional } \\
\text { study }\end{array}$ & 26 & $\mathrm{~N}$ & & $\begin{array}{l}\text { The PGS was significantly } \\
\text { associated with CDR-SB, MMSE, } \\
\text { and AD diagnosis. }\end{array}$ & $\begin{array}{l}\text { AD-specific cortical thickness was correlated } \\
\text { with the PGS, even after controlling for } A P O E \\
\text { genotype and CSF levels of } A \beta_{42} \text {. } \\
\text { The association remained significant in CN } \\
\text { subjects with levels of CSF } A \beta_{42} \text { in the normal } \\
\text { range and in } A P O E \& 3 \text { homozygotes. }\end{array}$ \\
\hline $\begin{array}{l}\text { Rodriguez- } \\
\text { Rodriguez et al., } \\
\quad 2013 \text { [90] }\end{array}$ & $228 \mathrm{MCI}$ & $\begin{array}{l}\text { Longitudinal study } \\
\text { (26.3 months) }\end{array}$ & 8 & $\mathrm{~N}$ & $\begin{array}{l}\text { PGS was not associated with risk of } \\
\text { conversion from MCI to AD. } \\
\text { MCI-converters to AD harboring six } \\
\text { or more risk alleles progressed } \\
\text { twofold more rapidly to AD when } \\
\text { compared with those with less than } \\
\text { six risk alleles. }\end{array}$ & & \\
\hline $\begin{array}{l}\text { Verhaaren et al., } \\
\quad 2013 \text { [91] }\end{array}$ & $\begin{array}{l}\text { Non-demented 5171 } \\
\text { (age range 45-99) }\end{array}$ & $\begin{array}{l}\text { Cross-sectional } \\
\text { study }\end{array}$ & 12 & Y & & $\begin{array}{l}\text { PGS was primarily associated } \\
\text { with memory. }\end{array}$ & \\
\hline $\begin{array}{l}\text { Marden et al., } \\
\quad 2014[92]\end{array}$ & $\begin{array}{l}10401 \text { (memory score } \\
\text { sample), } 7690 \text { (AD } \\
\text { probability scores) } \\
\text { non-Hispanic white } \\
\text { and black }\end{array}$ & $\begin{array}{l}\text { Cross-sectional } \\
\text { study }\end{array}$ & 10 & Y & $\begin{array}{l}\text { Each } 0.10 \text { unit change in PGS was } \\
\text { associated with larger relative effects } \\
\text { on dementia among aged } 65+\text {. }\end{array}$ & $\begin{array}{l}\text { Each } 0.10 \text { unit change in the PGS } \\
\text { was associated with a }-0.07 \\
\text { standard deviation difference in } \\
\text { memory score among aged } 50+.\end{array}$ & \\
\hline $\begin{array}{l}\text { Carrasquillo et al., } \\
2015 \text { [99] }\end{array}$ & CN 2674 & Longitudinal study & 10 & Y & $\begin{array}{l}\text { PGS was associated with progression } \\
\text { to } \mathrm{MCI} / \mathrm{LOAD} \text {. }\end{array}$ & $\begin{array}{l}\text { PGS was associated with } \\
\text { worse memory. }\end{array}$ & \\
\hline $\begin{array}{l}\text { Martiskainen et al., } \\
2015 \text { [164] }\end{array}$ & $\begin{array}{c}890 \mathrm{AD}(69.8 \pm 8.2) \\
\text { and } 701 \mathrm{CN} \\
(69.1 \pm 6.2)\end{array}$ & $\begin{array}{l}\text { Cross-sectional } \\
\text { study }\end{array}$ & 22 & $\mathrm{Y} / \mathrm{N}$ & & & $\begin{array}{l}\text { PGS associated with CSF A } \beta_{42} \text { levels in the } \\
\text { clinical cohort, and with soluble } A \beta_{42} \text { levels } \\
\text { and } \gamma \text {-secretase activity in the } \\
\text { neuropathological cohort. The } \gamma \text {-secretase } \\
\text { effect was independent of } A P O E \text {. }\end{array}$ \\
\hline $\begin{array}{l}\text { Xiao et al., } \\
2015 \text { [94] }\end{array}$ & $\begin{array}{l}459 \mathrm{AD}(71.2 \pm 9.6) \\
751 \mathrm{CN}(72.7 \pm 5.9) \\
\text { Chinese }\end{array}$ & $\begin{array}{l}\text { Cross-sectional } \\
\text { study }\end{array}$ & 3 & $\mathrm{~N}$ & $\begin{array}{l}\text { PGS significantly associated } \\
\text { with AD risk. }\end{array}$ & & \\
\hline $\begin{array}{l}\text { Sleegers et al., } \\
2015 \text { [89] }\end{array}$ & $\begin{array}{l}1162 \mathrm{AD}(74.4 \pm 8.9) \\
\text { and } 1019 \mathrm{CN} \\
(76.2 \pm 8.5)\end{array}$ & $\begin{array}{l}\text { Cross-sectional } \\
\text { study }\end{array}$ & 22 & Y & $\begin{array}{l}\text { Risk of AD increased with PGS; onset } \\
\text { age decreased with increasing PGS. }\end{array}$ & & CSF $A \beta_{42}$ decreased with increasing PGS. \\
\hline $\begin{array}{l}\text { Andrews et al., } \\
2016[98]\end{array}$ & $\begin{array}{l}\text { Non-demented } 1689 \\
\quad(62.54 \pm 1.51)\end{array}$ & Longitudinal study & 12 & $\mathrm{Y}$ & & $\begin{array}{l}\text { PGS was associated with worse } \\
\text { performance on } \\
\text { episodic memory. }\end{array}$ & \\
\hline $\begin{array}{l}\text { Harrison et al., } \\
2016[171]\end{array}$ & $\begin{array}{c}66 \text { baseline } \\
\text { participants } \\
(63.0 \pm 10.4) \text { and } 45 \\
\text { follow-up participants } \\
(63.2 \pm 7.8)\end{array}$ & $\begin{array}{l}\text { Longitudinal study } \\
\qquad(2 \text { years })\end{array}$ & 21 & $\mathrm{Y}$ & & & $\begin{array}{l}\text { Both unweighted risk score and weighted risk } \\
\text { score correlated strongly with the percentage } \\
\text { change in thickness across the whole } \\
\text { hippocampal complex, driven by a strong } \\
\text { relationship to entorhinal cortex thinning. By } \\
\text { contrast, at baseline, the risk scores showed no } \\
\text { relationship to thickness in any hippocampal } \\
\text { complex subregion. }\end{array}$ \\
\hline
\end{tabular}


Table 2. Cont

\begin{tabular}{|c|c|c|c|c|c|c|c|}
\hline Study & Participants & Study Design & SNP & $A P O E$ & Conversion Risk & Cognitive Impact & Neuroimaging Impact \\
\hline $\begin{array}{l}\text { Louwersheimer } \\
\text { et al., } 2016 \text { [97] }\end{array}$ & $\begin{array}{l}1730 \mathrm{MCI} \text { from } 4 \\
\text { independent datasets }\end{array}$ & Longitudinal study & 18 & $\mathrm{~N}$ & & $\begin{array}{c}\text { PGS was modestly associated } \\
\text { with cognitive decline over time. }\end{array}$ & $\begin{array}{l}\text { PGS was modestly associated with CSF levels } \\
\text { of tau and p-tau. }\end{array}$ \\
\hline $\begin{array}{l}\text { Lupton et al., } \\
2016 \text { [173] }\end{array}$ & $\begin{array}{l}1674 \text { older (aged }>53 \\
\text { years; } 17 \% \text { AD, } 39 \% \\
\text { MCI) and } 467 \text { young } \\
\text { (16-30 years) adults }\end{array}$ & $\begin{array}{l}\text { Cross-sectional } \\
\text { study }\end{array}$ & $\begin{array}{l}\text { Different } \\
\text { thresholds }\end{array}$ & $\mathrm{N}$ & & & $\begin{array}{l}\text { PGS associated with reduced hippocampal } \\
\text { volume in older } \mathrm{CN} \text { and MCI. No associations } \\
\text { were found in young adults. }\end{array}$ \\
\hline $\begin{array}{l}\text { Marden et al., } \\
2016 \text { [93] }\end{array}$ & $\begin{array}{l}8253 \text { non-Hispanic } \\
\text { whites and blacks }\end{array}$ & Longitudinal study & 22 & $\mathrm{Y} / \mathrm{N}$ & & $\begin{array}{l}\text { PGS can predict a more rapid } \\
\text { decline in memory in whites and } \\
\text { blacks; PGS without } A P O E \varepsilon 4 \\
\text { only can predict memory decline } \\
\text { in whites. }\end{array}$ & \\
\hline $\begin{array}{l}\text { Darst et al., } \\
2017 \text { [167] }\end{array}$ & $\begin{array}{l}1200 \text { at baseline } \\
\quad(53.6 \pm 6.6)\end{array}$ & Longitudinal study & 21 & Y & & $\begin{array}{l}\text { Non-significant for associations } \\
\text { between the PGS and } \\
\text { cognitive outcomes. }\end{array}$ & $\begin{array}{l}\text { These additional variants did not add much } \\
\text { predictive power over } A P O E \text { alone on } \\
\text { biomarkers of } \mathrm{A} \beta \text { deposition, } \\
\text { neurodegeneration and tau pathology. }\end{array}$ \\
\hline $\begin{array}{l}\text { Desikan et al., } \\
2017 \text { [172] }\end{array}$ & $\begin{array}{l}\text { More than } 80,000 \\
\text { people from two } \\
\text { projects }\end{array}$ & Longitudinal study & 31 & $\mathrm{~N}$ & $\begin{array}{l}\text { ADGC Phase 1: highest PGS quartile, } \\
\text { lower age onset and the highest } \\
\text { yearly AD incidence rate. APOE } \varepsilon 3 / 3 \\
\text { individuals: PGS modified expected } \\
\text { age of AD onset by more than } 10 \\
\text { years between the lowest and highest } \\
\text { deciles. Independent cohorts: PGS } \\
\text { strongly predicted empirical age of } \\
\text { AD onset and } \\
\text { longitudinal progression. }\end{array}$ & & $\begin{array}{l}\text { PGS was associated with neuropathology } \\
\text { (Braak stage of neurofibrillary tangles and } \\
\text { Consortium to Establish a Registry for } \\
\text { Alzheimer's Disease score for neurotic } \\
\text { plaques) and in vivo markers of AD } \\
\text { neurodegeneration (volume loss within the } \\
\text { entorhinal cortex and hippocampus) }\end{array}$ \\
\hline $\begin{array}{l}\text { Foley et al., } \\
2017 \text { [175] }\end{array}$ & $\begin{array}{l}272 \text { T1 }(24.8 \pm 6.9), \\
197 \text { DTI }(23.9 \pm 5.1), \\
87 \text { Hopkins Verbal } \\
\text { Learning Task } \\
(23.9 \pm 4.4)\end{array}$ & $\begin{array}{l}\text { Cross-sectional } \\
\text { study }\end{array}$ & $\begin{array}{l}7 \\
\text { thresholds }\end{array}$ & $\mathrm{Y} / \mathrm{N}$ & & & $\begin{array}{l}\text { A significant association between PGS and left } \\
\text { hippocampal volume; this effect remained } \\
\text { when the APOE gene was excluded. } \\
\text { The fractional anisotropy of the right } \\
\text { cingulum was inversely correlated with PGS. }\end{array}$ \\
\hline $\begin{array}{l}\text { Lacour et al., } \\
2017 \text { [96] }\end{array}$ & $\begin{array}{l}\text { 4 MCI groups } \\
853 / 812 / 1245 / 306\end{array}$ & Longitudinal study & 9 & $\mathrm{~N}$ & $\begin{array}{l}\text { PGS predicted a small effect on the } \\
\text { risk of MCI to AD progression in } \\
\text { APOE } \varepsilon 4 \text { carriers. }\end{array}$ & & \\
\hline $\begin{array}{l}\text { Voyle et al., } \\
2017 \text { [165] }\end{array}$ & $\begin{array}{l}\text { About } 250 \text { people with } \\
\text { normal and abnormal } \\
\text { CSF A } \beta \text { from ADNI }\end{array}$ & $\begin{array}{l}\text { Cross-sectional } \\
\text { study }\end{array}$ & - & $\mathrm{N}$ & & & $\begin{array}{c}\text { A case/control PGS is marginally more } \\
\text { predictive of } A \beta \text { and tau pathology than the } \\
\text { basic models (with age, gender and APOE } \\
\text { genotype). }\end{array}$ \\
\hline $\begin{array}{l}\text { Xiao et al., } \\
2017 \text { [174] }\end{array}$ & $\begin{array}{l}231 \mathrm{CN} \text { (age range } \\
19-55)\end{array}$ & $\begin{array}{l}\text { Cross-sectional } \\
\text { study }\end{array}$ & $\begin{array}{l}6 \\
\text { thresholds }\end{array}$ & $\mathrm{N}$ & & $\begin{array}{l}\text { Almost no significant association } \\
\text { of PGS with cognition. }\end{array}$ & $\begin{array}{l}\text { There was a significant negative relationship } \\
\text { between PGS and hippocampal function. }\end{array}$ \\
\hline $\begin{array}{l}\text { Ge et al., } \\
2018 \text { [104] }\end{array}$ & $\begin{array}{l}702 \text { participants }(221 \\
\mathrm{CN}, 367 \mathrm{MCI} \text {, and } 114 \\
\mathrm{AD} \text { ) and a subset of } \\
669 \text { participants }\end{array}$ & Longitudinal study & $\begin{array}{l}\text { Different } \\
\text { thresholds }\end{array}$ & $\mathrm{N}$ & & & $\begin{array}{c}\text { Only weak associations between PGS and } \\
\text { baseline } A \beta \text { were present. PGSs were } \\
\text { associated with hippocampal atrophy in } A \beta- \\
\text { and weakly associated with baseline } \\
\text { hippocampal volume in } A \beta+.\end{array}$ \\
\hline
\end{tabular}


Table 2. Cont

\begin{tabular}{|c|c|c|c|c|c|c|c|}
\hline Study & Participants & Study Design & SNP & APOE & Conversion Risk & Cognitive Impact & Neuroimaging Impact \\
\hline $\begin{array}{l}\text { Kauppi et al., } \\
2018 \text { [193] }\end{array}$ & $\begin{array}{l}336 \mathrm{MCI} \text { (baseline age } \\
\text { range 55-89) }\end{array}$ & $\begin{array}{l}\text { Longitudinal study } \\
\text { (3 year) }\end{array}$ & 31 & Y & $\begin{array}{l}\text { PGS significantly predicted time to } \\
\text { progression from MCI to AD over } 120 \\
\text { months, and PGS was significantly } \\
\text { more predictive than APOE alone. }\end{array}$ & $\begin{array}{l}\text { PGS improved the prediction of } \\
\text { change in the CDR-SB score and } \\
\text { MMSE over } 36 \text { months in MCI at } \\
\text { baseline, beyond both APOE and } \\
\text { baseline levels of brain atrophy. }\end{array}$ & \\
\hline $\begin{array}{l}\text { Li et al., } \\
2018 \text { [170] }\end{array}$ & $\begin{array}{l}360 \mathrm{CN}(19.4 \pm 1.1) \text { in } \\
\text { discovery dataset and } \\
323 \mathrm{CN}(22.7 \pm 2.5) \text { in } \\
\text { replication dataset }\end{array}$ & $\begin{array}{l}\text { Cross-sectional } \\
\text { study }\end{array}$ & - & $\mathrm{Y} / \mathrm{N}$ & & $\begin{array}{l}\text { No correlation between PGS and } \\
\text { any cognitive measure } \\
\text { in either sample. }\end{array}$ & $\begin{array}{c}\text { In both cohorts, an elevated PGS was } \\
\text { associated with a smaller precuneal volume, } \\
\text { and the effect remained after excluding the } \\
\text { APOE genotype. }\end{array}$ \\
\hline $\begin{array}{l}\text { Lin et al., } \\
2019 \text { [194] }\end{array}$ & $\begin{array}{l}2907 \text { stroke-free } \\
\text { individuals } \\
(76.73 \pm 5.83)\end{array}$ & $\begin{array}{l}\text { Cross-sectional } \\
\text { study }\end{array}$ & $\begin{array}{c}3 \\
\text { thresholds }\end{array}$ & $\mathrm{Y} / \mathrm{N}$ & & & $\begin{array}{l}\text { PGSs were associated with lobar cerebral } \\
\text { microbleeds, white-matter lesion load, } \\
\text { and coronary artery calcification, mostly } \\
\text { explained by single-nucleotide polymorphism } \\
\text { in the APOE region. The effect of PGS on } \\
\text { cognition was partially but significantly } \\
\text { mediated by cerebral microbleeds, } \\
\text { white-matter lesions, and coronary } \\
\text { artery calcification. }\end{array}$ \\
\hline $\begin{array}{l}\text { Tan et al., } \\
2018 \text { [166] }\end{array}$ & $\begin{array}{l}347 \mathrm{CN} \text { (baseline age } \\
\text { range 59.7-90.1), 599 } \\
\text { MCI (baseline age } \\
\text { range 54.4-91.4), } \\
\text { and } 485 \text { (age at death } \\
\text { range }=71.3-108.3 \text { ) in } \\
\text { another cohort }\end{array}$ & Longitudinal study & 31 & $\mathrm{~N}$ & & & $\begin{array}{l}\text { Even after accounting for } A P O E \varepsilon 4 \text { effects, } \\
\text { PGS may be useful in MCI and preclinical AD } \\
\text { therapeutic trials to enrich for } \\
\text { biomarker-positive individuals at highest risk } \\
\text { for short-term clinical progression. }\end{array}$ \\
\hline
\end{tabular}

$\mathrm{CN}$, cognitive normal; MCI, mild cognitive impairment; AD, Alzheimer's disease; PGS: polygenic risk score; Y, APOE included in PGS; N, APOE not included in PGS; Y /N, Both situations of $A P O E$ included and not in PGS; CDR-SB, Clinical Dementia Rating Sum of Boxes; MMSE, Mini-Mental State Examination; CSF, cerebrospinal fluid; ADGC, Alzheimer's Disease Genetics Consortium. 


\subsubsection{Study Design}

Longitudinal studies are needed. The effect of $A P O E \varepsilon 4$ is different depending on disease stage of $\mathrm{AD}$ [111], and longitudinal tracking of the same sample can more accurately describe the changes in the influence of the APOE gene on various biomarkers, establishing a better pathological change model. Functional MRI studies with improved designs are needed and would increase the interpretability of risk genes on specific cognitive abilities. However, there are currently few of these research designs, especially in the study of the APOE promoter, gene interaction, and polygenic risk factors. Some new techniques may also lead to interesting discoveries in this field, such as machine learning, virtual reality, and multimodal synchronous imaging. At the same time, researchers should be thinking about exploring the effect of non-risk alleles on risk genes, including the protective effect of $A P O E \varepsilon 2$ and its mechanism [195]. Some researchers found that drug interventions had better effects in people with APOE $\varepsilon 4$ [196]. The mechanism of this effect and whether it also happens with other risk genes should be addressed by further intervention studies.

\section{Conclusions}

Although the precise biological changes that cause AD are still not fully revealed, genetics remains a non-negligible factor in pathogenesis. Many genes, including the APOE gene, are related to AD risk. Thus, integrating different genetic loci and investigating polygenic risk is reasonable. Although some researchers considered the association between polygenic risk, cognition, and the brain, the studies are limited. The influence and mechanism of polygenic risk on cognition and the brain are still undefined. The interaction between polygenic risk and other AD risk factors (e.g., age, cardiovascular disease risk factors, education, and social and cognitive engagement) also warrants further study. Continued investigations integrating polygenic risk, the brain, and cognition will move the field closer to revealing the mechanism of $\mathrm{AD}$ pathogenesis.

Author Contributions: Conceptualization, J.F., W.T., and Y.C.; paper selection, J.F., W.T., X.L., H.L., J.Z., and D.W.; writing-original draft preparation, J.F. and W.T.; writing-review and editing, X.L., H.L., J.Z., and D.W.; supervision, Y.C. and Z.Z.; funding acquisition, Z.Z. All authors read and approved the final manuscript.

Funding: This research was supported by the National Science Fund for Distinguished Young Scholars (grant number 81625025), the Funds for International Cooperation and Exchange of the National Natural Science Foundation of China (grant number 81820108034), the National Key Research and Development Project of China (grant number 2018YFC1315200), the State Key Program of National Natural Science of China (grant number 81430100), the Beijing Municipal Science \& Technology Commission (grant number Z161100000216135), the National Natural Science Foundation of China (grant number 31700997 and 31500925), and the Fundamental Research Funds for the Central Universities (grant number 2017XTCX04).

Conflicts of Interest: The authors declare no conflicts of interest.

\section{References}

1. Patterson, C. World Alzheimer Report 2018-The State of the Art of Dementia Research: New Frontiers; Alzheimer's Disease International (ADI): London, UK, 2018.

2. Liu, C.C.; Liu, C.C.; Kanekiyo, T.; Xu, H.; Bu, G. Apolipoprotein E and Alzheimer disease: Risk, mechanisms and therapy. Nat. Rev. Neurol. 2013, 9, 106-118. [CrossRef] [PubMed]

3. Campion, D.; Dumanchin, C.; Hannequin, D.; Dubois, B.; Belliard, S.; Puel, M.; Thomas-Anterion, C.; Michon, A.; Martin, C.; Charbonnier, F. Early-Onset Autosomal Dominant Alzheimer Disease: Prevalence, Genetic Heterogeneity, and Mutation Spectrum. Am. J. Hum. Genet. 1999, 65, 664-670. [CrossRef] [PubMed]

4. Goate, A.; Chartier-Harlin, M.C.; Mullan, M.; Brown, J.; Crawford, F.; Fidani, L.; Giuffra, L.; Haynes, A.; Irving, N.; James, L.; et al. Segregation of a missense mutation in the amyloid precursor protein gene with familial Alzheimer's disease. Nature 1991, 349, 704-706. [CrossRef] [PubMed]

5. Sherrington, R.; Rogaev, E.I.; Liang, Y.; Rogaeva, E.A.; Levesque, G.; Ikeda, M.; Chi, H.; Lin, C.; Li, G.; Holman, K.; et al. Cloning of a gene bearing missense mutations in early-onset familial Alzheimer's disease. Nature 1995, 375, 754-760. [CrossRef] [PubMed] 
6. Levy-Lahad, E.; Wasco, W.; Poorkaj, P.; Romano, D.M.; Oshima, J.; Pettingell, W.H.; Yu, C.E.; Jondro, P.D.; Schmidt, S.D.; Wang, K.; et al. Candidate gene for the chromosome 1 familial Alzheimer's disease locus. Science 1995, 269, 973-977. [CrossRef] [PubMed]

7. Gatz, M.; Reynolds, C.A.; Fratiglioni, L.; Johansson, B.; Mortimer, J.A.; Berg, S.; Fiske, A.; Pedersen, N.L. Role of genes and environments for explaining Alzheimer disease. Arch. Gen. Psychiatry 2006, 63, 168-174. [CrossRef] [PubMed]

8. Kamboh, M.I. Molecular genetics of late-onset Alzheimer's disease. Ann. Hum. Genet. 2012, 68, $381-404$. [CrossRef] [PubMed]

9. Lambert, J.C. Meta-analysis in more than 74,000 individuals identifies 11 new susceptibility loci for Alzheimer's disease. Alzheimers Dement. 2013, 9, 1452-1458. [CrossRef]

10. Avila, J.; Gomez-Ramos, A.; Bolos, M. AD genetic risk factors and tau spreading. Front. Aging Neurosci. 2015, 7, 99. [CrossRef] [PubMed]

11. Harold, D.; Abraham, R.; Hollingworth, P.; Sims, R.; Gerrish, A.; Hamshere, M.L.; Pahwa, J.S.; Moskvina, V.; Dowzell, K.; Williams, A. Genome-wide association study identifies variants at CLU and PICALM associated with Alzheimer's disease. Nat. Genet. 2009, 41, 1088. [CrossRef] [PubMed]

12. Karch, C.M.; Goate, A.M. Alzheimer's Disease Risk Genes and Mechanisms of Disease Pathogenesis. Biol. Psychiatry 2015, 77, 43-51. [CrossRef] [PubMed]

13. Zannis, V.I.; Just, P.W.; Breslow, J.L. Human apolipoprotein E isoprotein subclasses are genetically determined. Am. J. Hum. Genet. 1981, 33, 11. [PubMed]

14. Singh, P.P.; Singh, M.; Mastana, S.S. APOE distribution in world populations with new data from India and the UK. Ann. Hum. Biol. 2006, 33, 279-308. [CrossRef] [PubMed]

15. Gerdes, L.U.; Gerdes, C.; Hansen, P.S.; Klausen, I.C.; Faergeman, O.; Dyerberg, J. The apolipoprotein E polymorphism in Greenland Inuit in its global perspective. Hum. Genet. 1996, 98, 546-550. [CrossRef] [PubMed]

16. Giau, V.V.; Bagyinszky, E.; An, S.S.; Kim, S.Y. Role of apolipoprotein E in neurodegenerative diseases. Neuropsychiatr. Dis. Treat. 2015, 11, 1723-1737. [CrossRef] [PubMed]

17. Ward, A.; Crean, S.; Mercaldi, C.J.; Collins, J.M.; Boyd, D.; Cook, M.N.; Arrighi, H.M. Prevalence of apolipoprotein E4 genotype and homozygotes (APOE e4/4) among patients diagnosed with Alzheimer's disease: A systematic review and meta-analysis. Neuroepidemiology 2012, 38, 1-17. [CrossRef] [PubMed]

18. Kwon, O.D.; Khaleeq, A.; Chan, W.; Pavlik, V.N.; Doody, R.S. Apolipoprotein E polymorphism and age at onset of Alzheimer's disease in a quadriethnic sample. Dement. Geriatr. Cogn. Disord. 2010, 30, 486-491. [CrossRef] [PubMed]

19. Sando, S.B.; Melquist, S.; Cannon, A.; Hutton, M.L.; Sletvold, O.; Saltvedt, I.; White, L.R.; Lydersen, S.; Aasly, J.O. APOE epsilon 4 lowers age at onset and is a high risk factor for Alzheimer's disease; a case control study from central Norway. BMC Neurol. 2008, 8, 9. [CrossRef] [PubMed]

20. Corder, E.H.; Saunders, A.M.; Strittmatter, W.J.; Schmechel, D.E.; Gaskell, P.C.; Small, G.W.; Roses, A.D.; Haines, J.L.; Pericak-Vance, M.A. Gene dose of apolipoprotein E type 4 allele and the risk of Alzheimer's disease in late onset families. Science 1993, 261, 921. [CrossRef] [PubMed]

21. Farrer, L.A.; Cupples, L.A.; Haines, J.L.; Hyman, B.; Kukull, W.A.; Mayeux, R.; Myers, R.H.; PericakVance, M.A.; Risch, N.; van Duijn, C.M. Effects of age, sex, and ethnicity on the association between apolipoprotein E genotype and Alzheimer disease-A meta-analysis. JAMA 1997, 278, 1349-1356. [CrossRef] [PubMed]

22. Petersen, R.C. Mild cognitive impairment: Transition between aging and Alzheimer's disease. Neurologia 2000, 15, 93-101. [CrossRef]

23. Ma, F.; Wang, J. Apolipoprotein $\varepsilon 4$-allele as a significant risk factor for conversion from mild cognitive impairment to Alzheimer's disease: A meta-analysis of prospective studies. J. Mol. Neurosci. 2013, 50, 257-263. [CrossRef]

24. Elias-Sonnenschein, L.S.; Wolfgang, V.; Ramakers, I.H.G.B.; Verhey, F.R.J.; Pieter Jelle, V. Predictive value of APOE- $\varepsilon 4$ allele for progression from MCI to AD-type dementia: A meta-analysis. J. Neurol. Neurosurg. Psychiatry 2011, 82, 1149-1156. [CrossRef] [PubMed] 
25. Nickerson, D.A.; Taylor, S.L.; Fullerton, S.M.; Weiss, K.M.; Clark, A.G.; Stengard, J.H.; Salomaa, V.; Boerwinkle, E.; Sing, C.F. Sequence diversity and large-scale typing of SNPs in the human apolipoprotein E gene. Genome Res. 2000, 10, 1532-1545. [CrossRef] [PubMed]

26. Richard, P.; Thomas, G.; de Zulueta, M.P.; De Gennes, J.L.; Thomas, M.; Cassaigne, A.; Bereziat, G.; Iron, A. Common and rare genotypes of human apolipoprotein $\mathrm{E}$ determined by specific restriction profiles of polymerase chain reaction-amplified DNA. Clin. Chem. 1994, 40, 24-29. [PubMed]

27. Yamamura, T.; Dong, L.M.; Yamamoto, A. Characterization of apolipoprotein E7 (Glu(244)->Lys, $\mathrm{Glu}(245) \longrightarrow$ Lys), a mutant apolipoprotein E associated with hyperlipidemia and atherosclerosis. J. Lipid Res. 1999, 40, 253-259. [PubMed]

28. Youn, Y.C.; Lim, Y.K.; Han, S.-H.; Giau, V.V.; Lee, M.-K.; Park, K.-Y.; Kim, S.; Bagyinszky, E.; An, S.S.A.; Kim, H.R. Apolipoprotein $\varepsilon 7$ allele in memory complaints: Insights through protein structure prediction. Clin. Interv. Aging 2017, 12, 1095-1102. [CrossRef] [PubMed]

29. Bizzarro, A.; Seripa, D.; Acciarri, A.; Matera, M.G.; Pilotto, A.; Tiziano, F.D.; Brahe, C.; Masullo, C. The complex interaction between APOE promoter and AD: An Italian case-control study. Eur. J. Hum. Genet. 2009, 17, 938-945. [CrossRef] [PubMed]

30. Laws, S.M.; Hone, E.; Gandy, S.; Martins, R.N. Expanding the association between the APOE gene and the risk of Alzheimer's disease: Possible roles for APOE promoter polymorphisms and alterations in APOE transcription. J. Neurochem. 2003, 84, 1215-1236. [CrossRef] [PubMed]

31. Artiga, M.J.; Bullido, M.J.; Sastre, I.; Recuero, M.; Garcia, M.A.; Aldudo, J.; Vazquez, J.; Valdivieso, F. Allelic polymorphisms in the transcriptional regulatory region of apolipoprotein E gene. FEBS Lett 1998, 421, 105-108. [CrossRef]

32. Xin, X.Y.; Ding, J.Q.; Chen, S.D. Apolipoprotein E promoter polymorphisms and risk of Alzheimer's disease: Evidence from meta-analysis. J. Alzheimers Dis. 2010, 19, 1283-1294. [CrossRef] [PubMed]

33. Xiao, H.; Gao, Y.; Liu, L.; Li, Y. Association between polymorphisms in the promoter region of the apolipoprotein E (APOE) gene and Alzheimer's disease: A meta-analysis. EXCLI J 2017, 16, 921-938. [CrossRef] [PubMed]

34. Farlow, M.R.; He, Y.; Tekin, S.; Xu, J.; Xu, J.; Charles, H.C. Impact of APOE in mild cognitive impairment. Neurology 2004, 63, 1898-1901. [CrossRef] [PubMed]

35. El Haj, M.; Antoine, P.; Amouyel, P.; Lambert, J.C.; Pasquier, F.; Kapogiannis, D. Apolipoprotein E (APOE) epsilon4 and episodic memory decline in Alzheimer's disease: A review. Ageing Res. Rev. 2016, 27, 15-22. [CrossRef] [PubMed]

36. O'Donoghue, M.C.; Murphy, S.E.; Zamboni, G.; Nobre, A.C.; Mackay, C.E. APOE genotype and cognition in healthy individuals at risk of Alzheimer's disease: A review. Cortex 2018, 104, 103-123. [CrossRef] [PubMed]

37. McKhann, G.M.; Knopman, D.S.; Chertkow, H.; Hyman, B.T.; Jack, C.R.; Kawas, C.H.; Klunk, W.E.; Koroshetz, W.J.; Manly, J.J.; Mayeux, R.; et al. The diagnosis of dementia due to Alzheimer's disease: Recommendations from the National Institute on Aging-Alzheimer's Association workgroups on diagnostic guidelines for Alzheimer's disease. Alzheimers Dement. 2011, 7, 263-269. [CrossRef] [PubMed]

38. Van der Vlies, A.E.; Pijnenburg, Y.A.; Koene, T.; Klein, M.; Kok, A.; Scheltens, P.; van der Flier, W.M. Cognitive impairment in Alzheimer's disease is modified by APOE genotype. Dement. Geriatr. Cogn. Disord. 2007, 24, 98-103. [CrossRef] [PubMed]

39. Snowden, J.S.; Stopford, C.L.; Julien, C.L.; Thompson, J.C.; Davidson, Y.; Gibbons, L.; Pritchard, A.; Lendon, C.L.; Richardson, A.M.; Varma, A. Cognitive Phenotypes in Alzheimer's Disease and Genetic Risk. Cortex 2007, 43, 835-845. [CrossRef]

40. Wolk, D.A.; Dickerson, B.C. Apolipoprotein E (APOE) genotype has dissociable effects on memory and attentional-executive network function in Alzheimer's disease. Proc. Natl. Acad. Sci. USA 2010, 107, 10256-10261. [CrossRef] [PubMed]

41. Kim, J.; Park, S.; Yoo, H.; Jang, H.; Kim, Y.; Kim, K.W.; Jang, Y.K.; Lee, J.S.; Kim, S.T.; Kim, S.; et al. The Impact of APOE varepsilon4 in Alzheimer's Disease Differs According to Age. J. Alzheimers Dis. 2018, 61, 1377-1385. [CrossRef] [PubMed]

42. Cosentino, S.; Scarmeas, N.; Helzner, E.; Glymour, M.M.; Brandt, J.; Albert, M.; Blacker, D.; Stern, Y. APOE epsilon 4 allele predicts faster cognitive decline in mild Alzheimer disease. Neurology 2008, 70, 1842-1849. [CrossRef] [PubMed] 
43. Chang, Y.L.; Fennema-Notestine, C.; Holland, D.; McEvoy, L.K.; Stricker, N.H.; Salmon, D.P.; Dale, A.M.; Bondi, M.W.; Alzheimer's Disease Neuroimaging Initiative. APOE interacts with age to modify rate of decline in cognitive and brain changes in Alzheimer's disease. Alzheimers Dement. 2014, 10, 336-348. [CrossRef] [PubMed]

44. Ramakers, I.H.; Visser, P.J.; Aalten, P.; Bekers, O.; Sleegers, K.; van Broeckhoven, C.L.; Jolles, J.; Verhey, F.R. The association between APOE genotype and memory dysfunction in subjects with mild cognitive impairment is related to age and Alzheimer pathology. Dement. Geriatr. Cogn. Disord. 2008, 26, 101-108. [CrossRef] [PubMed]

45. Whitehair, D.C.; Sherzai, A.; Emond, J.; Raman, R.; Aisen, P.S.; Petersen, R.C.; Fleisher, A.S.; Alzheimer's Disease Neuroimaging Initiative. Influence of apolipoprotein E varepsilon4 on rates of cognitive and functional decline in mild cognitive impairment. Alzheimers Dement. 2010, 6, 412-419. [CrossRef] [PubMed]

46. Foster, J.K.; Albrecht, M.A.; Greg, S.; Lautenschlager, N.T.; Ellis, K.A.; Paul, M.; Cassandra, S.; Kevin, T.; Ralph, M.; Masters, C.L. Lack of reliable evidence for a distinctive $\varepsilon$ 4-related cognitive phenotype that is independent from clinical diagnostic status: Findings from the Australian Imaging, Biomarkers and Lifestyle Study. Brain 2013, 136, 2201-2216. [CrossRef] [PubMed]

47. Lyall, D.M.; Ward, J.; Ritchie, S.J.; Davies, G.; Cullen, B.; Celis, C.; Bailey, M.E.; Anderson, J.; Evans, J.; McKay, D.F.; et al. Alzheimer disease genetic risk factor APOE e4 and cognitive abilities in 111,739 UK Biobank participants. Age Ageing 2016, 45, 511-517. [CrossRef] [PubMed]

48. Wisdom, N.M.; Callahan, J.L.; Hawkins, K.A. The effects of apolipoprotein E on non-impaired cognitive functioning: A meta-analysis. Neurobiol. Aging 2011, 32, 63-74. [CrossRef] [PubMed]

49. Schultz, M.R.; Lyons, M.J.; Franz, C.E.; Grant, M.D.; Boake, C.; Jacobson, K.C.; Xian, H.; Schellenberg, G.D.; Eisen, S.A.; Kremen, W.S. Apolipoprotein E genotype and memory in the sixth decade of life. Neurology 2008, 70, 1771-1777. [CrossRef] [PubMed]

50. Liu, F.; Pardo, L.M.; Schuur, M.; Sanchez-Juan, P.; Isaacs, A.; Sleegers, K.; de Koning, I.; Zorkoltseva, I.V.; Axenovich, T.I.; Witteman, J.C.; et al. The apolipoprotein E gene and its age-specific effects on cognitive function. Neurobiol. Aging 2010, 31, 1831-1833. [CrossRef] [PubMed]

51. Kerchner, G.A.; Berdnik, D.; Shen, J.C.; Bernstein, J.D.; Fenesy, M.C.; Deutsch, G.K.; Wyss-Coray, T.; Rutt, B.K. APOE epsilon4 worsens hippocampal CA1 apical neuropil atrophy and episodic memory. Neurology 2014, 82, 691-697. [CrossRef] [PubMed]

52. Espeseth, T.; Westlye, L.T.; Fjell, A.M.; Walhovd, K.B.; Rootwelt, H.; Reinvang, I. Accelerated age-related cortical thinning in healthy carriers of apolipoprotein E $\varepsilon 4$. Neurobiol. Aging 2008, 29, 329-340. [CrossRef] [PubMed]

53. Luciano, M.; Gow, A.J.; Harris, S.E.; Hayward, C.; Allerhand, M.; Starr, J.M.; Visscher, P.M.; Deary, I.J. Cognitive ability at age 11 and 70 years, information processing speed, and APOE variation: The Lothian Birth Cohort 1936 study. Psychol. Aging 2009, 24, 129. [CrossRef] [PubMed]

54. Izaks, G.J.; Gansevoort, R.T.; van der Knaap, A.M.; Navis, G.; Dullaart, R.P.F.; Slaets, J.P.J. The association of APOE genotype with cognitive function in persons aged 35 years or older. PLoS ONE 2011, 6, e27415. [CrossRef] [PubMed]

55. Quintino-Santos, S.; Diniz, B.S.; Firmo, J.O.; Moriguchi, E.H.; Lima-Costa, M.F.; Castro-Costa, E. APOE epsilon4 allele is associated with worse performance in memory dimensions of the mini-mental state examination: The Bambui Cohort Study of Aging. Int. J. Geriatr. Psychiatry 2015, 30, 573-579. [CrossRef] [PubMed]

56. Caselli, R.J.; Dueck, A.C.; Osborne, D.; Sabbagh, M.N.; Connor, D.J.; Ahern, G.L.; Baxter, L.C.; Rapcsak, S.Z.; Shi, J.; Woodruff, B.K.; et al. Longitudinal modeling of age-related memory decline and the APOE epsilon4 effect. N. Engl. J. Med. 2009, 361, 255-263. [CrossRef] [PubMed]

57. Caselli, R.J.; Dueck, A.C.; Locke, D.E.; Hoffman-Snyder, C.R.; Woodruff, B.K.; Rapcsak, S.Z.; Reiman, E.M. Longitudinal modeling of frontal cognition in APOE epsilon4 homozygotes, heterozygotes, and noncarriers. Neurology 2011, 76, 1383-1388. [CrossRef] [PubMed]

58. Schiepers, O.J.; Harris, S.E.; Gow, A.J.; Pattie, A.; Brett, C.E.; Starr, J.M.; Deary, I.J. APOE E4 status predicts age-related cognitive decline in the ninth decade: Longitudinal follow-up of the Lothian Birth Cohort 1921. Mol. Psychiatry 2012, 17, 315-324. [CrossRef] [PubMed]

59. Rawle, M.J.; Davis, D.; Bendayan, R.; Wong, A.; Kuh, D.; Richards, M. Apolipoprotein-E (Apoe) epsilon4 and cognitive decline over the adult life course. Transl. Psychiatry 2018, 8, 18. [CrossRef] [PubMed] 
60. Barnes, L.L.; Arvanitakis, Z.; Yu, L.; Kelly, J.; De Jager, P.L.; Bennett, D.A. Apolipoprotein E and change in episodic memory in blacks and whites. Neuroepidemiology 2013, 40, 211-219. [CrossRef] [PubMed]

61. Hendrie, H.C.; Murrell, J.; Baiyewu, O.; Lane, K.A.; Purnell, C.; Ogunniyi, A.; Unverzagt, F.W.; Hall, K.; Callahan, C.M.; Saykin, A.J.; et al. APOE epsilon4 and the risk for Alzheimer disease and cognitive decline in African Americans and Yoruba. Int. Psychogeriatr. 2014, 26, 977-985. [CrossRef] [PubMed]

62. Lipnicki, D.M.; Crawford, J.D.; Dutta, R.; Thalamuthu, A.; Kochan, N.A.; Andrews, G.; Lima-Costa, M.F.; Castro-Costa, E.; Brayne, C.; Matthews, F.E.; et al. Age-related cognitive decline and associations with sex, education and apolipoprotein $\mathrm{E}$ genotype across ethnocultural groups and geographic regions: A collaborative cohort study. PLoS Med. 2017, 14, e1002261. [CrossRef] [PubMed]

63. Tuminello, E.R.; Han, S.D. The apolipoprotein e antagonistic pleiotropy hypothesis: Review and recommendations. Int. J. Alzheimers Dis. 2011, 2011, 726197. [CrossRef] [PubMed]

64. Lancaster, C.; Tabet, N.; Rusted, J. The APOE paradox: Do attentional control differences in mid-adulthood reflect risk of late-life cognitive decline. Neurobiol. Aging 2016, 48, 114-121. [CrossRef] [PubMed]

65. Shu, N.; Li, X.; Ma, C.; Zhang, J.; Chen, K.; Liang, Y.; Chen, Y.; Zhang, Z. Effects of APOE promoter polymorphism on the topological organization of brain structural connectome in nondemented elderly. Hum. Brain Mapp. 2015, 36, 4847-4858. [CrossRef] [PubMed]

66. Chang, P.; Li, X.; Ma, C.; Zhang, S.; Liu, Z.; Chen, K.; Ai, L.; Chang, J.; Zhang, Z. The Effects of an APOE Promoter Polymorphism on Human White Matter Connectivity during Non-Demented Aging. J. Alzheimers Dis. 2017, 55, 77-87. [CrossRef] [PubMed]

67. Chen, Y.; Li, P.; Gu, B.; Liu, Z.; Li, X.; Evans, A.C.; Gong, G.; Zhang, Z. The effects of an APOE promoter polymorphism on human cortical morphology during nondemented aging. J. Neurosci. 2015, 35, 1423-1431. [CrossRef] [PubMed]

68. Ma, C.; Zhang, Y.; Li, X.; Zhang, J.; Chen, K.; Liang, Y.; Chen, Y.; Liu, Z.; Zhang, Z. Is there a significant interaction effect between apolipoprotein $\mathrm{E}$ rs405509 $\mathrm{T} / \mathrm{T}$ and epsilon4 genotypes on cognitive impairment and gray matter volume? Eur. J. Neurol. 2016, 23, 1415-1425. [CrossRef] [PubMed]

69. Rantalainen, V.; Lahti, J.; Henriksson, M.; Kajantie, E.; Tienari, P.; Eriksson, J.G.; Raikkonen, K. APOE and aging-related cognitive change in a longitudinal cohort of men. Neurobiol. Aging 2016, 44, 151-158. [CrossRef] [PubMed]

70. Martinez, M.F.; Martin, X.E.; Alcelay, L.G.; Flores, J.C.; Valiente, J.M.; Juanbeltz, B.I.; Beldarrain, M.A.; Lopez, J.M.; Gonzalez-Fernandez, M.C.; Salazar, A.M.; et al. The COMT Val158 Met polymorphism as an associated risk factor for Alzheimer disease and mild cognitive impairment in APOE 4 carriers. BMC Neurosci. 2009, 10, 125. [CrossRef] [PubMed]

71. Ward, D.D.; Summers, M.J.; Saunders, N.L.; Janssen, P.; Stuart, K.E.; Vickers, J.C. APOE and BDNF Val66Met polymorphisms combine to influence episodic memory function in older adults. Behav. Brain Res. 2014, 271, 309-315. [CrossRef] [PubMed]

72. Gomar, J.J.; Conejero-Goldberg, C.; Huey, E.D.; Davies, P.; Goldberg, T.E.; Alzheimer's Disease Neuroimaging Initiative. Lack of neural compensatory mechanisms of BDNF val66met met carriers and APOE E4 carriers in healthy aging, mild cognitive impairment, and Alzheimer's disease. Neurobiol. Aging 2016, 39, 165-173. [CrossRef] [PubMed]

73. Persson, N.; Lavebratt, C.; Wahlin, A. Synergy effects of HbA1c and variants of APOE and BDNFVal66Met explains individual differences in memory performance. Neurobiol. Learn. Mem. 2013, 106, $274-282$. [CrossRef] [PubMed]

74. Thow, M.E.; Summers, M.J.; Summers, J.J.; Saunders, N.L.; Vickers, J.C. Variations in the APOE allele or BDNF Val66Met polymorphism are not associated with changes in cognitive function following a tertiary education intervention in older adults: The Tasmanian Healthy Brain Project. Neurobiol. Aging 2017, 55, 175-176. [CrossRef] [PubMed]

75. Wang, P.N.; Liu, H.C.; Liu, T.Y.; Chu, A.; Hong, C.J.; Lin, K.N.; Chi, C.W. Estrogen-metabolizing gene COMT polymorphism synergistic APOE epsilon4 allele increases the risk of Alzheimer disease. Dement. Geriatr. Cogn. Disord. 2005, 19, 120-125. [CrossRef] [PubMed]

76. Sapkota, S.; Backman, L.; Dixon, R.A. Executive function performance and change in aging is predicted by apolipoprotein $\mathrm{E}$, intensified by catechol-O-methyltransferase and brain-derived neurotrophic factor, and moderated by age and lifestyle. Neurobiol. Aging 2017, 52, 81-89. [CrossRef] [PubMed] 
77. Yu, C.-E.; Seltman, H.; Peskind, E.R.; Galloway, N.; Zhou, P.X.; Rosenthal, E.; Wijsman, E.M.; Tsuang, D.W.; Devlin, B.; Schellenberg, G.D. Comprehensive analysis of APOE and selected proximate markers for late-onset Alzheimer's disease: Patterns of linkage disequilibrium and disease/marker association. Genomics 2007, 89, 655-665. [CrossRef] [PubMed]

78. Roses, A.D.; Lutz, M.W.; Amrine-Madsen, H.; Saunders, A.M.; Crenshaw, D.G.; Sundseth, S.S.; Huentelman, M.J.; Welsh-Bohmer, K.A.; Reiman, E.M. A TOMM40 variable-length polymorphism predicts the age of late-onset Alzheimer's disease. Pharmacogenom. J. 2009, 10, 375. [CrossRef] [PubMed]

79. Lutz, M.W.; Crenshaw, D.; Welsh-Bohmer, K.A.; Burns, D.K.; Roses, A.D. New Genetic Approaches to AD: Lessons from APOE-TOMM40 Phylogenetics. Curr. Neurol. Neurosci. Rep. 2016, 16, 48. [CrossRef] [PubMed]

80. Johnson, S.C.; Rue, A.L.; Hermann, B.P.; Xu, G.; Koscik, R.L.; Jonaitis, E.M.; Bendlin, B.B.; Hogan, K.J.; Roses, A.D.; Saunders, A.M. The effect of TOMM40 poly-T length on gray matter volume and cognition in middle-aged persons with APOE $\varepsilon 3 / \varepsilon 3$ genotype. Alzheimers Dement. 2011, 7, 456-465. [CrossRef] [PubMed]

81. Yu, L.; Lutz, M.W.; Wilson, R.S.; Burns, D.K.; Roses, A.D.; Saunders, A.M.; Gaiteri, C.; De Jager, P.L.; Barnes, L.L.; Bennett, D.A. TOMM40'523 variant and cognitive decline in older persons with APOE epsilon3/3 genotype. Neurology 2017, 88, 661-668. [CrossRef] [PubMed]

82. Louwersheimer, E.; Cohn-Hokke, P.E.; Pijnenburg, Y.A.; Weiss, M.M.; Sistermans, E.A.; Rozemuller, A.J.; Hulsman, M.; van Swieten, J.C.; van Duijn, C.M.; Barkhof, F.; et al. Rare Genetic Variant in SORL1 May Increase Penetrance of Alzheimer's Disease in a Family with Several Generations of APOE-varepsilon4 Homozygosity. J. Alzheimers Dis. 2017, 56, 63-74. [CrossRef] [PubMed]

83. Barral, S.; Bird, T.; Goate, A.; Farlow, M.R.; Diaz-Arrastia, R.; Bennett, D.A.; Graff-Radford, N.; Boeve, B.F.; Sweet, R.A.; Stern, Y.; et al. Genotype patterns at PICALM, CR1, BIN1, CLU, and APOE genes are associated with episodic memory. Neurology 2012, 78, 1464-1471. [CrossRef] [PubMed]

84. Gharesouran, J.; Rezazadeh, M.; Khorrami, A.; Ghojazadeh, M.; Talebi, M. Genetic evidence for the involvement of variants at APOE, BIN1, CR1, and PICALM loci in risk of late-onset Alzheimer's disease and evaluation for interactions with APOE genotypes. J. Mol. Neurosci. 2014, 54, 780-786. [CrossRef] [PubMed]

85. Keenan, B.T.; Shulman, J.M.; Chibnik, L.B.; Raj, T.; Tran, D.; Sabuncu, M.R.; Alzheimer's Disease Neuroimaging Initiative; Allen, A.N.; Corneveaux, J.J.; Hardy, J.A.; et al. A coding variant in CR1 interacts with APOE-epsilon4 to influence cognitive decline. Hum. Mol. Genet. 2012, 21, 2377-2388. [CrossRef] [PubMed]

86. Liao, Y.C.; Lee, W.J.; Hwang, J.P.; Wang, Y.F.; Tsai, C.F.; Wang, P.N.; Wang, S.J.; Fuh, J.L. ABCA7 gene and the risk of Alzheimer's disease in Han Chinese in Taiwan. Neurobiol. Aging 2014, 35, 2423. [CrossRef] [PubMed]

87. Casati, M.; Ferri, E.; Gussago, C.; Mazzola, P.; Abbate, C.; Bellelli, G.; Mari, D.; Cesari, M.; Arosio, B. Increased expression of TREM2 in peripheral cells from mild cognitive impairment patients who progress into Alzheimer's disease. Eur. J. Neurol. 2018, 25, 805-810. [CrossRef] [PubMed]

88. Jendresen, C.; Arskog, V.; Daws, M.R.; Nilsson, L.N.G. The Alzheimer's disease risk factors apolipoprotein E and TREM2 are linked in a receptor signaling pathway. J. Neuroinflamm. 2017, 14, 59. [CrossRef] [PubMed]

89. Sleegers, K.; Bettens, K.; De Roeck, A.; Van Cauwenberghe, C.; Cuyvers, E.; Verheijen, J.; Struyfs, H.; Van Dongen, J.; Vermeulen, S.; Engelborghs, S.; et al. A 22-single nucleotide polymorphism Alzheimer's disease risk score correlates with family history, onset age, and cerebrospinal fluid Abeta42. Alzheimers Dement. 2015, 11, 1452-1460. [CrossRef] [PubMed]

90. Rodríguez-Rodríguez, E.; Sánchez-Juan, P.; Vázquez-Higuera, J.L.; Mateo, I.; Pozueta, A.; Berciano, J.; Cervantes, S.; Alcolea, D.; Martinez-Lage, P.; Clarimón, J. Genetic risk score predicting accelerated progression from mild cognitive impairment to Alzheimer's disease. J. Neural Transm. 2013, 120, 807-812. [CrossRef] [PubMed]

91. Verhaaren, B.F.J.; Vernooij, M.W.; Koudstaal, P.J.; Uitterlinden, A.G.; Duijn, C.M.V.; Hofman, A.; Breteler, M.M.B.; Ikram, M.A. Alzheimer's Disease Genes and Cognition in the Nondemented General Population. Biol. Psychiatry 2013, 73, 429-434. [CrossRef] [PubMed]

92. Marden, J.R.; Walter, S.; Tchetgen Tchetgen, E.J.; Kawachi, I.; Glymour, M.M. Validation of a polygenic risk score for dementia in black and white individuals. Brain Behav. 2014, 4, 687-697. [CrossRef] [PubMed]

93. Marden, J.R.; Mayeda, E.R.; Walter, S.; Vivot, A.; Tchetgen, E.J.T.; Kawachi, I.; Glymour, M.M. Using an Alzheimer Disease Polygenic Risk Score to Predict Memory Decline in Black and White Americans Over 14 Years of Follow-up. Alzheimer Dis. Assoc. Disord. 2016, 30, 195-202. [CrossRef] [PubMed] 
94. Qianyi, X.; Zhi-Jun, L.; Sha, T.; Yi-Min, S.; Deke, J.; Hong-Lei, L.; Haitao, C.; Xu, L.; Brittany, L.; Chi-Hsiung, W. Risk prediction for sporadic Alzheimer's disease using genetic risk score in the Han Chinese population. Oncotarget 2015, 6, 36955-36964.

95. Lee, J.J.; Kang, S.; Lee, W.; Gunasekaran, T.I.; Gim, J.; Wi, S.O.; Kang, D.O.; Choo, I.; Kim, B.C.; Kim, H.; et al. Risk prediction of alzheimer's disease with age stratification using polygenic risk scores. Alzheimers Dement. 2018, 14, P339-P340. [CrossRef]

96. Lacour, A.; Espinosa, A.; Louwersheimer, E.; Heilmann, S.; Hernández, I.; Wolfsgruber, S.; Fernández, V.; Wagner, H.; Rosende-Roca, M.; Mauleón, A.; et al. Genome-wide significant risk factors for Alzheimer's disease: Role in progression to dementia due to Alzheimer's disease among subjects with mild cognitive impairment. Mol. Psychiatry 2017, 22, 153-160. [CrossRef] [PubMed]

97. Louwersheimer, E.; Wolfsgruber, S.; Espinosa, A.; Lacour, A.; Heilmann-Heimbach, S.; Alegret, M.; Hernandez, I.; Rosende-Roca, M.; Tarraga, L.; Boada, M.; et al. Alzheimer's disease risk variants modulate endophenotypes in mild cognitive impairment. Alzheimers Dement. 2016, 12, 872-881. [CrossRef] [PubMed]

98. Andrews, S.J.; Das, D.; Cherbuin, N.; Anstey, K.J.; Easteal, S. Association of genetic risk factors with cognitive decline: The PATH through life project. Neurobiol. Aging 2016, 41, 150-158. [CrossRef] [PubMed]

99. Carrasquillo, M.M.; Crook, J.E.; Pedraza, O.; Thomas, C.S.; Pankratz, V.S.; Allen, M.; Nguyen, T.; Malphrus, K.G.; Ma, L.; Bisceglio, G.D. Late-onset Alzheimer's risk variants in memory decline, incident mild cognitive impairment, and Alzheimer's disease. Neurobiol. Aging 2015, 36, 60-67. [CrossRef] [PubMed]

100. Liu, Y.; Yu, J.T.; Wang, H.F.; Han, P.R.; Tan, C.C.; Wang, C.; Meng, X.F.; Risacher, S.L.; Saykin, A.J.; Tan, L. APOE genotype and neuroimaging markers of Alzheimer's disease: Systematic review and meta-analysis. J. Neurol. Neurosurg. Psychiatry 2015, 86, 127-134. [CrossRef] [PubMed]

101. Jansen, W.J.; Rik, O.; Knol, D.L.; Tijms, B.M.; Philip, S.; Verhey, F.R.J.; Pieter Jelle, V.; Pauline, A.; Dag, A.; Daniel, A. Prevalence of cerebral amyloid pathology in persons without dementia: A meta-analysis. JAMA 2015, 313, 1924-1938. [CrossRef] [PubMed]

102. Drzezga, A.; Grimmer, T.; Henriksen, G.; Muhlau, M.; Perneczky, R.; Miederer, I.; Praus, C.; Sorg, C.; Wohlschlager, A.; Riemenschneider, M.; et al. Effect of APOE genotype on amyloid plaque load and gray matter volume in Alzheimer disease. Neurology 2009, 72, 1487-1494. [CrossRef] [PubMed]

103. Grimmer, T.; Tholen, S.; Yousefi, B.H.; Alexopoulos, P.; Forschler, A.; Forstl, H.; Henriksen, G.; Klunk, W.E.; Mathis, C.A.; Perneczky, R.; et al. Progression of cerebral amyloid load is associated with the apolipoprotein E epsilon4 genotype in Alzheimer's disease. Biol. Psychiatry 2010, 68, 879-884. [CrossRef] [PubMed]

104. Ge, T.; Sabuncu, M.R.; Smoller, J.W.; Sperling, R.A.; Mormino, E.C.; Alzheimer's Disease Neuroimaging Initiative. Dissociable influences of APOE epsilon4 and polygenic risk of AD dementia on amyloid and cognition. Neurology 2018, 90, e1605-e1612. [CrossRef] [PubMed]

105. Scheinin, N.M.; Wikman, K.; Jula, A.; Perola, M.; Vahlberg, T.; Rokka, J.; Nagren, K.; Viitanen, M.; Rinne, J.O. Cortical (1)(1)C-PIB uptake is associated with age, APOE genotype, and gender in "healthy aging". J. Alzheimers Dis. 2014, 41, 193-202. [CrossRef] [PubMed]

106. Fleisher, A.S.; Kewei, C.; Xiaofen, L.; Napatkamon, A.; Auttawut, R.; Pradeep, T.; Hillary, P.; Joshi, A.D.; Marwan, S.; Sadowsky, C.H. Apolipoprotein E $\varepsilon 4$ and age effects on florbetapir positron emission tomography in healthy aging and Alzheimer disease. Neurobiol. Aging 2013, 34, 1-12. [CrossRef] [PubMed]

107. Gonneaud, J.; Arenaza-Urquijo, E.M.; Fouquet, M.; Perrotin, A.; Fradin, S.; de La Sayette, V.; Eustache, F.; Chetelat, G. Relative effect of APOE epsilon4 on neuroimaging biomarker changes across the lifespan. Neurology 2016, 87, 1696-1703. [CrossRef] [PubMed]

108. Mielke, M.M.; Machulda, M.M.; Hagen, C.E.; Christianson, T.J.; Roberts, R.O.; Knopman, D.S.; Vemuri, P.; Lowe, V.J.; Kremers, W.K.; Jack, C.R., Jr.; et al. Influence of amyloid and APOE on cognitive performance in a late middle-aged cohort. Alzheimers Dement. 2016, 12, 281-291. [CrossRef] [PubMed]

109. Kantarci, K.; Lowe, V.; Przybelski, S.A.; Weigand, S.D.; Senjem, M.L.; Ivnik, R.J.; Preboske, G.M.; Roberts, R.; Geda, Y.E.; Boeve, B.F.; et al. APOE modifies the association between Abeta load and cognition in cognitively normal older adults. Neurology 2012, 78, 232-240. [CrossRef] [PubMed]

110. Wirth, M.; Villeneuve, S.; La Joie, R.; Marks, S.M.; Jagust, W.J. Gene-environment interactions: Lifetime cognitive activity, APOE genotype, and beta-amyloid burden. J. Neurosci. 2014, 34, 8612-8617. [CrossRef] [PubMed] 
111. Liu, Y.; Tan, L.; Wang, H.F.; Liu, Y.; Hao, X.K.; Tan, C.C.; Jiang, T.; Liu, B.; Zhang, D.Q.; Yu, J.T.; et al. Multiple Effect of APOE Genotype on Clinical and Neuroimaging Biomarkers Across Alzheimer's Disease Spectrum. Mol. Neurobiol. 2016, 53, 4539-4547. [CrossRef] [PubMed]

112. Vemuri, P.; Wiste, H.J.; Weigand, S.D.; Knopman, D.S.; Shaw, L.M.; Trojanowski, J.Q.; Aisen, P.S.; Weiner, M.; Petersen, R.C.; Jack, C.R., Jr.; et al. Effect of apolipoprotein E on biomarkers of amyloid load and neuronal pathology in Alzheimer disease. Ann. Neurol. 2010, 67, 308-316. [CrossRef] [PubMed]

113. Risacher, S.L.; Kim, S.; Shen, L.; Nho, K.; Foroud, T.; Green, R.C.; Petersen, R.C.; Jack, C.R., Jr.; Aisen, P.S.; Koeppe, R.A.; et al. The role of apolipoprotein E (APOE) genotype in early mild cognitive impairment (E-MCI). Front. Aging Neurosci. 2013, 5, 11. [CrossRef] [PubMed]

114. Crary, J.F.; Trojanowski, J.Q.; Schneider, J.A.; Abisambra, J.F.; Abner, E.L.; Irina, A.; Arnold, S.E.; Johannes, A.; Beach, T.G.; Bigio, E.H. Primary age-related tauopathy (PART): A common pathology associated with human aging. Acta Neuropathol. 2014, 128, 755-766. [CrossRef] [PubMed]

115. Farfel, J.M.; Yu, L.; De Jager, P.L.; Schneider, J.A.; Bennett, D.A. Association of APOE with tau-tangle pathology with and without $\beta$-amyloid. Neurobiol. Aging 2015, 37, 19. [CrossRef] [PubMed]

116. Lautner, R.; Palmqvist, S.; Mattsson, N.; Andreasson, U.; Wallin, A.; Palsson, E.; Jakobsson, J.; Herukka, S.K.; Owenius, R.; Olsson, B.; et al. Apolipoprotein E genotype and the diagnostic accuracy of cerebrospinal fluid biomarkers for Alzheimer disease. JAMA Psychiatry 2014, 71, 1183-1191. [CrossRef] [PubMed]

117. Wolf, A.B.; Caselli, R.J.; Reiman, E.M.; Jon, V. APOE and neuroenergetics: An emerging paradigm in Alzheimer's disease. Neurobiol. Aging 2013, 34, 1007-1017. [CrossRef] [PubMed]

118. Reiman, E.M.; Caselli, R.J.; Yun, L.S.; Chen, K.; Bandy, D.; Minoshima, S.; Thibodeau, S.N.; Osborne, D. Preclinical evidence of Alzheimer's disease in persons homozygous for the epsilon 4 allele for apolipoprotein E. N. Engl. J. Med. 1996, 334, 752-758. [CrossRef] [PubMed]

119. Reiman, E.M.; Kewei, C.; Alexander, G.E.; Caselli, R.J.; Daniel, B.; David, O.; Saunders, A.M.; John, H. Functional brain abnormalities in young adults at genetic risk for late-onset Alzheimer's dementia. Proc. Natl. Acad. Sci. USA 2004, 101, 284-289. [CrossRef] [PubMed]

120. Nielsen, H.M.; Chen, K.; Lee, W.; Chen, Y.; Bauer, R.J.; Reiman, E.; Caselli, R.; Bu, G. Peripheral apoE isoform levels in cognitively normal APOE $\varepsilon 3 / \varepsilon 4$ individuals are associated with regional gray matter volume and cerebral glucose metabolism. Alzheimers Res. Ther. 2017, 9, 5. [CrossRef] [PubMed]

121. Brandon, J.A.; Farmer, B.C.; Williams, H.C.; Johnson, L.A. APOE and Alzheimer's Disease: Neuroimaging of Metabolic and Cerebrovascular Dysfunction. Front. Aging Neurosci. 2018, 10, 180. [CrossRef] [PubMed]

122. Zhao, N.; Liu, C.C.; Ingelgom, A.J.V.; Martens, Y.A.; Linares, C.; Knight, J.A.; Painter, M.M.; Sullivan, P.M.; $\mathrm{Bu}, \mathrm{G}$. Apolipoprotein E4 Impairs Neuronal Insulin Signaling by Trapping Insulin Receptor in the Endosomes. Neuron 2017, 96, 115-129. [CrossRef] [PubMed]

123. Valla, J.; Yaari, R.; Wolf, A.B.; Kusne, Y.; Beach, T.G.; Roher, A.E.; Corneveaux, J.J.; Huentelman, M.J.; Caselli, R.J.; Reiman, E.M. Reduced posterior cingulate mitochondrial activity in expired young adult carriers of the APOE epsilon4 allele, the major late-onset Alzheimer's susceptibility gene. J. Alzheimers Dis. 2010, 22, 307-313. [CrossRef] [PubMed]

124. Cherbuin, N.; Leach, L.S.; Christensen, H.; Anstey, K.J. Neuroimaging and APOE genotype: A systematic qualitative review. Dement. Geriatr. Cogn. Disord. 2007, 24, 348-362. [CrossRef] [PubMed]

125. Saeed, U.; Mirza, S.S.; MacIntosh, B.J.; Herrmann, N.; Keith, J.; Ramirez, J.; Nestor, S.M.; Yu, Q.; Knight, J.; Swardfager, W.; et al. APOE-epsilon4 associates with hippocampal volume, learning, and memory across the spectrum of Alzheimer's disease and dementia with Lewy bodies. Alzheimers Dement. 2018, 14, 1137-1147. [CrossRef] [PubMed]

126. Gutierrez-Galve, L.; Lehmann, M.; Hobbs, N.Z.; Clarkson, M.J.; Ridgway, G.R.; Crutch, S.; Ourselin, S.; Schott, J.M.; Fox, N.C.; Barnes, J. Patterns of cortical thickness according to APOE genotype in Alzheimer's disease. Dement. Geriatr. Cogn. Disord. 2009, 28, 476-485. [CrossRef] [PubMed]

127. Pievani, M.; Rasser, P.E.; Galluzzi, S.; Benussi, L.; Ghidoni, R.; Sabattoli, F.; Bonetti, M.; Binetti, G.; Thompson, P.M.; Frisoni, G.B. Mapping the effect of APOE epsilon4 on gray matter loss in Alzheimer's disease in vivo. Neuroimage 2009, 45, 1090-1098. [CrossRef] [PubMed]

128. Donix, M.; Burggren, A.C.; Suthana, N.A.; Siddarth, P.; Ekstrom, A.D.; Krupa, A.K.; Jones, M.; Rao, A.; Martin-Harris, L.; Ercoli, L.M.; et al. Longitudinal changes in medial temporal cortical thickness in normal subjects with the APOE-4 polymorphism. Neuroimage 2010, 53, 37-43. [CrossRef] [PubMed] 
129. Mishra, S.; Blazey, T.M.; Holtzman, D.M.; Cruchaga, C.; Su, Y.; Morris, J.C.; Benzinger, T.L.S.; Gordon, B.A. Longitudinal brain imaging in preclinical Alzheimer disease: Impact of APOE epsilon4 genotype. Brain 2018, 141, 1828-1839. [CrossRef] [PubMed]

130. Adamson, M.M.; Landy, K.M.; Duong, S.; Fox-Bosetti, S.; Ashford, J.W.; Murphy, G.M.; Weiner, M.; Taylor, J.L. Apolipoprotein E epsilon4 influences on episodic recall and brain structures in aging pilots. Neurobiol. Aging 2010, 31, 1059-1063. [CrossRef] [PubMed]

131. Lim, Y.Y.; Williamson, R.; Laws, S.M.; Villemagne, V.L.; Bourgeat, P.; Fowler, C.; Rainey-Smith, S.; Salvado, O.; Martins, R.N.; Rowe, C.C.; et al. Effect of APOE Genotype on Amyloid Deposition, Brain Volume, and Memory in Cognitively Normal Older Individuals. J. Alzheimers Dis. 2017, 58, 1293-1302. [CrossRef] [PubMed]

132. Khan, W.; Giampietro, V.; Banaschewski, T.; Barker, G.J.; Bokde, A.L.; Buchel, C.; Conrod, P.; Flor, H.; Frouin, V.; Garavan, H.; et al. A Multi-Cohort Study of ApoE varepsilon4 and Amyloid-beta Effects on the Hippocampus in Alzheimer's Disease. J. Alzheimers Dis. 2017, 56, 1159-1174. [CrossRef] [PubMed]

133. Habes, M.; Toledo, J.B.; Resnick, S.M.; Doshi, J.; Van der Auwera, S.; Erus, G.; Janowitz, D.; Hegenscheid, K.; Homuth, G.; Volzke, H.; et al. Relationship between APOE Genotype and Structural MRI Measures throughout Adulthood in the Study of Health in Pomerania Population-Based Cohort. AJNR Am. J. Neuroradiol. 2016, 37, 1636-1642. [CrossRef] [PubMed]

134. Bunce, D.; Anstey, K.J.; Cherbuin, N.; Gautam, P.; Sachdev, P.; Easteal, S. APOE genotype and entorhinal cortex volume in non-demented community-dwelling adults in midlife and early old age. J. Alzheimers Dis. 2012, 30, 935-942. [CrossRef] [PubMed]

135. Honea, R.A.; Vidoni, E.; Harsha, A.; Burns, J.M. Impact of APOE on the healthy aging brain: A voxel-based MRI and DTI study. J. Alzheimers Dis. 2009, 18, 553-564. [CrossRef] [PubMed]

136. Bagepally, B.S.; Halahalli, H.N.; John, J.P.; Kota, L.; Purushottam, M.; Mukherjee, O.; Sivakumar, P.T.; Bharath, S.; Jain, S.; Varghese, M. Apolipoprotein E4 and brain white matter integrity in Alzheimer's disease: Tract-based spatial statistics study under 3-Tesla MRI. Neurodegener. Dis. 2012, 10, 145-148. [CrossRef] [PubMed]

137. Cai, S.; Jiang, Y.; Wang, Y.; Wu, X.; Ren, J.; Lee, M.S.; Lee, S.; Huang, L. Modulation on brain gray matter activity and white matter integrity by APOE epsilon4 risk gene in cognitively intact elderly: A multimodal neuroimaging study. Behav. Brain Res. 2017, 322, 100-109. [CrossRef] [PubMed]

138. Verghese, P.B.; Castellano, J.M.; Holtzman, D.M. Apolipoprotein E in Alzheimer's disease and other neurological disorders. Lancet Neurol. 2011, 10, 241-252. [CrossRef]

139. Smith, C.D.; Andersen, A.H.; Kryscio, R.J.; Schmitt, F.A.; Kindy, M.S.; Blonder, L.X.; Avison, M.J. Altered brain activation in cognitively intact individuals at high risk for Alzheimer's disease. Neurology 1999, 53, 1391. [CrossRef] [PubMed]

140. Trachtenberg, A.J.; Filippini, N.; Mackay, C.E. The effects of APOE- $\varepsilon 4$ on the BOLD response. Neurobiol. Aging 2012, 33, 323-334. [CrossRef] [PubMed]

141. Chen, Y.; Liu, Z.; Zhang, J.; Chen, K.; Yao, L.; Li, X.; Gong, G.; Wang, J.; Zhang, Z. Precuneus degeneration in nondemented elderly individuals with APOE varepsilon4: Evidence from structural and functional MRI analyses. Hum. Brain Mapp. 2017, 38, 271-282. [CrossRef] [PubMed]

142. Chen, C.J.; Chen, C.C.; Wu, D.; Chi, N.F.; Chen, P.C.; Liao, Y.P.; Chiu, H.W.; Hu, C.J. Effects of the apolipoprotein E epsilon4 allele on functional MRI during n-back working memory tasks in healthy middle-aged adults. AJNR Am. J. Neuroradiol. 2013, 34, 1197-1202. [CrossRef] [PubMed]

143. Matura, S.; Prvulovic, D.; Hartmann, D.; Scheibe, M.; Sepanski, B.; Butz, M.; Oertel-Knochel, V.; Knochel, C.; Karakaya, T.; Fusser, F.; et al. Age-Related Effects of the Apolipoprotein E Gene on Brain Function. J. Alzheimers Dis. 2016, 52, 317-331. [CrossRef] [PubMed]

144. Shu, H.; Shi, Y.; Chen, G.; Wang, Z.; Liu, D.; Yue, C.; Ward, B.D.; Li, W.; Xu, Z.; Chen, G.; et al. Opposite Neural Trajectories of Apolipoprotein E 4 and 2 Alleles with Aging Associated with Different Risks of Alzheimer's Disease. Cereb. Cortex 2016, 26, 1421-1429. [CrossRef] [PubMed]

145. Goveas, J.S.; Xie, C.; Chen, G.; Li, W.; Ward, B.D.; Franczak, M.B.; Jones, J.L.; Antuono, P.G.; Li, S.J. Functional network endophenotypes unravel the effects of apolipoprotein E epsilon 4 in middle-aged adults. PLoS ONE 2013, 8, e55902. [CrossRef] [PubMed] 
146. Heise, V.; Filippini, N.; Trachtenberg, A.J.; Suri, S.; Ebmeier, K.P.; Mackay, C.E. Apolipoprotein E genotype, gender and age modulate connectivity of the hippocampus in healthy adults. Neuroimage 2014, 98, 23-30. [CrossRef] [PubMed]

147. Shu, H.; Yuan, Y.; Xie, C.; Bai, F.; You, J.; Li, L.; Li, S.J.; Zhang, Z. Imbalanced hippocampal functional networks associated with remitted geriatric depression and apolipoprotein E epsilon4 allele in nondemented elderly: A preliminary study. J. Affect. Disord. 2014, 164, 5-13. [CrossRef] [PubMed]

148. Risacher, S.L.; Kim, S.; Nho, K.; Foroud, T.; Shen, L.; Petersen, R.C.; Jack, C.R., Jr.; Beckett, L.A.; Aisen, P.S.; Koeppe, R.A.; et al. APOE effect on Alzheimer's disease biomarkers in older adults with significant memory concern. Alzheimers Dement. 2015, 11, 1417-1429. [CrossRef] [PubMed]

149. Song, H.; Long, H.; Zuo, X.; Yu, C.; Liu, B.; Wang, Z.; Wang, Q.; Wang, F.; Han, Y.; Jia, J. APOE Effects on Default Mode Network in Chinese Cognitive Normal Elderly: Relationship with Clinical Cognitive Performance. PLoS ONE 2015, 10, e0133179. [CrossRef] [PubMed]

150. Yuan, B.; Xie, C.; Shu, H.; Liao, W.; Wang, Z.; Liu, D.; Zhang, Z. Differential Effects of APOE Genotypes on the Anterior and Posterior Subnetworks of Default Mode Network in Amnestic Mild Cognitive Impairment. J. Alzheimers Dis. 2016, 54, 1409-1423. [CrossRef] [PubMed]

151. Luo, X.; Qiu, T.; Jia, Y.; Huang, P.; Xu, X.; Yu, X.; Shen, Z.; Jiaerken, Y.; Guan, X.; Zhou, J.; et al. Intrinsic functional connectivity alterations in cognitively intact elderly APOE epsilon4 carriers measured by eigenvector centrality mapping are related to cognition and CSF biomarkers: A preliminary study. Brain Imaging Behav. 2017, 11, 1290-1301. [CrossRef] [PubMed]

152. Luo, X.; Li, K.; Jia, Y.L.; Zeng, Q.; Jiaerken, Y.; Qiu, T.; Huang, P.; Xu, X.; Shen, Z.; Guan, X.; et al. Altered effective connectivity anchored in the posterior cingulate cortex and the medial prefrontal cortex in cognitively intact elderly APOE epsilon4 carriers: A preliminary study. Brain Imaging Behav. 2018. [CrossRef] [PubMed]

153. Lambert, J.C.; Mann, D.; Goumidi, L.; Harris, J.; Amouyel, P.; Iwatsubo, T.; Lendon, C.; Chartier-Harlin, M.C. Effect of the APOE promoter polymorphisms on cerebral amyloid peptide deposition in Alzheimer's disease. Lancet 2001, 357, 608-609. [CrossRef]

154. Pahnke, J.; Walker, L.C.; Schroeder, E.; Vogelgesang, S.; Stausske, D.; Walther, R.; Warzok, R.W. Cerebral beta-amyloid deposition is augmented by the -491AA promoter polymorphism in non-demented elderly individuals bearing the apolipoprotein E epsilon4 allele. Acta Neuropathol. 2003, 105, 25-29. [CrossRef] [PubMed]

155. Chalmers, K.A.; Culpan, D.; Kehoe, P.G.; Wilcock, G.K.; Hughes, A.; Love, S. APOE promoter, ACE1 and CYP46 polymorphisms and beta-amyloid in Alzheimer's disease. Neuroreport 2004, 15, 95-98. [CrossRef] [PubMed]

156. Ma, C.; Zhang, Y.; Li, X.; Chen, Y.; Zhang, J.; Liu, Z.; Chen, K.; Zhang, Z. The TT allele of rs405509 synergizes with APOE epsilon4 in the impairment of cognition and its underlying default mode network in non-demented elderly. Curr. Alzheimer Res. 2016, 13, 708-717. [CrossRef] [PubMed]

157. Espeseth, T.; Greenwood, P.M.; Reinvang, I.; Fjell, A.M.; Walhovd, K.B.; Westlye, L.T.; Wehling, E.; Lundervold, A.; Rootwelt, H.; Parasuraman, R. Interactive effects of APOE and CHRNA4 on attention and white matter volume in healthy middle-aged and older adults. Cogn. Affect. Behav. Neurosci. 2006, 6, 31-43. [CrossRef] [PubMed]

158. Morgen, K.; Ramirez, A.; Frolich, L.; Tost, H.; Plichta, M.M.; Kolsch, H.; Rakebrandt, F.; Rienhoff, O.; Jessen, F.; Peters, O.; et al. Genetic interaction of PICALM and APOE is associated with brain atrophy and cognitive impairment in Alzheimer's disease. Alzheimers Dement. 2014, 10, S269-S276. [CrossRef] [PubMed]

159. Thambisetty, M.; An, Y.; Nalls, M.; Sojkova, J.; Swaminathan, S.; Zhou, Y.; Singleton, A.B.; Wong, D.F.; Ferrucci, L.; Saykin, A.J.; et al. Effect of complement CR1 on brain amyloid burden during aging and its modification by APOE genotype. Biol. Psychiatry 2013, 73, 422-428. [CrossRef] [PubMed]

160. Liu, Z.; Dai, X.; Tao, W.; Liu, H.; Li, H.; Yang, C.; Zhang, J.; Li, X.; Chen, Y.; Ma, C.; et al. APOE influences working memory in non-demented elderly through an interaction with SPON1 rs2618516. Hum. Brain Mapp. 2018, 39, 2859-2867. [CrossRef] [PubMed]

161. Shen, J.; Qin, W.; Xu, Q.; Xu, L.; Xu, J.; Zhang, P.; Liu, H.; Liu, B.; Jiang, T.; Yu, C. Modulation of APOE and SORL1 genes on hippocampal functional connectivity in healthy young adults. Brain Struct. Funct. 2017, 222, 2877-2889. [CrossRef] [PubMed] 
162. Zhang, N.; Liu, H.; Qin, W.; Liu, B.; Jiang, T.; Yu, C. APOE and KIBRA Interactions on Brain Functional Connectivity in Healthy Young Adults. Cereb. Cortex 2017, 27, 4797-4805. [CrossRef] [PubMed]

163. Porter, T.; Burnham, S.C.; Dore, V.; Savage, G.; Bourgeat, P.; Begemann, K.; Milicic, L.; Ames, D.; Bush, A.I.; Maruff, P.; et al. KIBRA is associated with accelerated cognitive decline and hippocampal atrophy in APOE epsilon4-positive cognitively normal adults with high Abeta-amyloid burden. Sci. Rep. 2018, 8, 2034. [CrossRef] [PubMed]

164. Martiskainen, H.; Helisalmi, S.; Viswanathan, J.; Kurki, M.; Hall, A.; Herukka, S.K.; Sarajarvi, T.; Natunen, T.; Kurkinen, K.M.; Huovinen, J.; et al. Effects of Alzheimer's disease-associated risk loci on cerebrospinal fluid biomarkers and disease progression: A polygenic risk score approach. J. Alzheimers Dis. 2015, 43, 565-573. [CrossRef] [PubMed]

165. Voyle, N.; Patel, H.; Folarin, A.; Newhouse, S.; Johnston, C.; Visser, P.J.; Dobson, R.J.; Kiddle, S.J. Genetic Risk as a Marker of Amyloid-beta and Tau Burden in Cerebrospinal Fluid. J. Alzheimers Dis. 2017, 55, 1417-1427. [CrossRef] [PubMed]

166. Tan, C.H.; Fan, C.C.; Mormino, E.C.; Sugrue, L.P.; Broce, I.J.; Hess, C.P.; Dillon, W.P.; Bonham, L.W.; Yokoyama, J.S.; Karch, C.M.; et al. Polygenic hazard score: An enrichment marker for Alzheimer's associated amyloid and tau deposition. Acta Neuropathol. 2018, 135, 85-93. [CrossRef] [PubMed]

167. Darst, B.F.; Koscik, R.L.; Racine, A.M.; Oh, J.M.; Krause, R.A.; Carlsson, C.M.; Zetterberg, H.; Blennow, K.; Christian, B.T.; Bendlin, B.B.; et al. Pathway-Specific Polygenic Risk Scores as Predictors of Amyloid-beta Deposition and Cognitive Function in a Sample at Increased Risk for Alzheimer's Disease. J. Alzheimers Dis. 2017, 55, 473-484. [CrossRef] [PubMed]

168. Sabuncu, M.R.; Buckner, R.L.; Smoller, J.W.; Lee, P.H.; Fischl, B.; Sperling, R.A.; Alzheimer's Disease Neuroimaging Initiative. The association between a polygenic Alzheimer score and cortical thickness in clinically normal subjects. Cereb. Cortex 2012, 22, 2653-2661. [CrossRef] [PubMed]

169. Corlier, F.; Hafzalla, G.; Faskowitz, J.; Kuller, L.H.; Becker, J.T.; Lopez, O.L.; Thompson, P.M.; Braskie, M.N. Systemic inflammation as a predictor of brain aging: Contributions of physical activity, metabolic risk, and genetic risk. Neuroimage 2018, 172, 118-129. [CrossRef] [PubMed]

170. Li, J.; Zhang, X.; Li, A.; Liu, S.; Qin, W.; Yu, C.; Liu, Y.; Liu, B.; Jiang, T. Polygenic risk for Alzheimer's disease influences precuneal volume in two independent general populations. Neurobiol. Aging 2018, 64, 116-122. [CrossRef] [PubMed]

171. Harrison, T.M.; Mahmood, Z.; Lau, E.P.; Karacozoff, A.M.; Burggren, A.C.; Small, G.W.; Bookheimer, S.Y. An Alzheimer's Disease Genetic Risk Score Predicts Longitudinal Thinning of Hippocampal Complex Subregions in Healthy Older Adults. eNeuro 2016, 3. [CrossRef] [PubMed]

172. Desikan, R.S.; Fan, C.C.; Wang, Y.; Schork, A.J.; Cabral, H.J.; Cupples, L.A.; Thompson, W.K.; Besser, L.; Kukull, W.A.; Holland, D.; et al. Genetic assessment of age-associated Alzheimer disease risk: Development and validation of a polygenic hazard score. PLoS Med. 2017, 14, e1002258. [CrossRef] [PubMed]

173. Lupton, M.K.; Strike, L.; Hansell, N.K.; Wen, W.; Mather, K.A.; Armstrong, N.J.; Thalamuthu, A.; McMahon, K.L.; de Zubicaray, G.I.; Assareh, A.A.; et al. The effect of increased genetic risk for Alzheimer's disease on hippocampal and amygdala volume. Neurobiol. Aging 2016, 40, 68-77. [CrossRef] [PubMed]

174. Xiao, E.; Chen, Q.; Goldman, A.L.; Tan, H.Y.; Healy, K.; Zoltick, B.; Das, S.; Kolachana, B.; Callicott, J.H.; Dickinson, D.; et al. Late-Onset Alzheimer's Disease Polygenic Risk Profile Score Predicts Hippocampal Function. Biol. Psychiatry Cogn. Neurosci. Neuroimaging 2017, 2, 673-679. [CrossRef] [PubMed]

175. Foley, S.F.; Tansey, K.E.; Caseras, X.; Lancaster, T.; Bracht, T.; Parker, G.; Hall, J.; Williams, J.; Linden, D.E. Multimodal Brain Imaging Reveals Structural Differences in Alzheimer's Disease Polygenic Risk Carriers: A Study in Healthy Young Adults. Biol. Psychiatry 2017, 81, 154-161. [CrossRef] [PubMed]

176. Laukka, E.J.; Lövdén, M.; Herlitz, A.; Karlsson, S.; Ferencz, B.; Pantzar, A.; Keller, L.; Graff, C.; Fratiglioni, L.; Bäckman, L. Genetic effects on old-age cognitive functioning: A population-based study. Psychol. Aging 2013, 28, 262-274. [CrossRef] [PubMed]

177. Ihle, A.; Bunce, D.; Kliegel, M. APOE $\varepsilon 4$ and Cognitive Function in Early Life: A meta-analysis. Neuropsychology 2012, 26, 267-277. [CrossRef] [PubMed]

178. Bathum, L.; Christiansen, L.B.; Vaupel, J.; Mcgue, M.; Christensen, K. Apolipoprotein e genotypes: Relationship to cognitive functioning, cognitive decline, and survival in nonagenarians. J. Am. Geriatr. Soc. 2010, 54, 654-658. [CrossRef] [PubMed] 
179. Østbye, T. Neuropsychological performance in advanced age: Influences of Demographic factors and Apolipoprotein E: Findings from the Cache County Memory Study. Clin. Neuropsychol. 2009, 23, 77-99.

180. Bunce, D.; Bielak, A.A.; Anstey, K.J.; Cherbuin, N.; Batterham, P.J.; Easteal, S. APOE genotype and cognitive change in young, middle-aged, and older adults living in the community. J. Gerontol. A Biol. Sci. Med. Sci. 2014, 69, 379-386. [CrossRef] [PubMed]

181. Han, S.D.; Bondi, M.W. Revision of the apolipoprotein E compensatory mechanism recruitment hypothesis. Alzheimers Dement. 2008, 4, 251-254. [CrossRef] [PubMed]

182. Carrion-Baralt, J.R.; Melendez-Cabrero, J.; Rodriguez-Ubinas, H.; Schmeidler, J.; Beeri, M.S.; Angelo, G.; Sano, M.; Silverman, J.M. Impact of APOE epsilon4 on the cognitive performance of a sample of non-demented Puerto Rican nonagenarians. J. Alzheimers Dis. 2009, 18, 533-540. [CrossRef] [PubMed]

183. Duchek, J.M.; Balota, D.A.; Cortese, M. Prospective memory and apolipoprotein E in healthy aging and early stage Alzheimer's disease. Neuropsychology 2006, 20, 633-644. [CrossRef] [PubMed]

184. Bloss, C.S.; Delis, D.C.; Salmon, D.P.; Bondi, M.W. Decreased cognition in children with risk factors for Alzheimer's disease. Biol. Psychiatry 2008, 64, 904-906. [CrossRef] [PubMed]

185. Woodard, J.L.; Seidenberg, M.; Nielson, K.A.; Antuono, P.; Guidotti, L.; Durgerian, S.; Zhang, Q.; Lancaster, M.; Hantke, N.; Butts, A. Semantic memory activation in amnestic mild cognitive impairment. Brain 2009, 132, 2068. [CrossRef] [PubMed]

186. Johnson, S.C.; Schmitz, T.W.; Trivedi, M.A.; Ries, M.L.; Torgerson, B.M.; Carlsson, C.M.; Asthana, S.; Hermann, B.P.; Sager, M.A. The influence of Alzheimer disease family history and apolipoprotein E epsilon4 on mesial temporal lobe activation. J. Neurosci. 2006, 26, 6069-6076. [CrossRef] [PubMed]

187. Roberts, G.W.; Gentleman, S.M.; Lynch, A.; Graham, D.I. beta A4 amyloid protein deposition in brain after head trauma. Lancet 1991, 338, 1422-1423. [CrossRef]

188. Teasdale, G.M.; Nicoll, J.A.; Murray, G.; Fiddes, M. Association of apolipoprotein E polymorphism with outcome after head injury. Lancet 1997, 350, 1069-1071. [CrossRef]

189. Irie, F.; Fitzpatrick, A.; Kuller, O.L.; Peila, R.; Newman, A.; Launer, L. Enhanced risk for Alzheimer disease in persons with type 2 diabetes and APOE epsilon4: The Cardiovascular Health Study Cognition Study. Arch. Neurol. 2008, 65, 89-93. [CrossRef] [PubMed]

190. Profenno, L.A.; Faraone, S.V. Diabetes and overweight associate with non-APOE4 genotype in an Alzheimer's disease population. Am. J. Med. Genet. B Neuropsychiatr. Genet. 2010, 147B, 822-829. [CrossRef] [PubMed]

191. Ihab, H.; Farzaneh, S.; Lipsitz, L.A. Apolipoprotein e, carbon dioxide vasoreactivity, and cognition in older adults: Effect of hypertension. J. Am. Geriatr. Soc. 2015, 63, 276-281.

192. Giri, M.; Zhang, M.; Yang, L. Genes associated with Alzheimer's disease: An overview and current status. Clin. Interv. Aging 2016, 11, 665-681. [CrossRef] [PubMed]

193. Kauppi, K.; Fan, C.C.; McEvoy, L.K.; Holland, D.; Tan, C.H.; Chen, C.H.; Andreassen, O.A.; Desikan, R.S.; Dale, A.M.; Alzheimer's Disease Neuroimaging Initiative. Combining Polygenic Hazard Score With Volumetric MRI and Cognitive Measures Improves Prediction of Progression From Mild Cognitive Impairment to Alzheimer's Disease. Front. Neurosci. 2018, 12, 260. [CrossRef] [PubMed]

194. Lin, Y.F.; Smith, A.V.; Aspelund, T.; Betensky, R.A.; Smoller, J.W.; Gudnason, V.; Launer, L.J.; Blacker, D. Genetic overlap between vascular pathologies and Alzheimer's dementia and potential causal mechanisms. Alzheimers Dement 2019, 15, 65-75. [CrossRef] [PubMed]

195. Suri, S.; Heise, V.; Trachtenberg, A.J.; Mackay, C.E. The forgotten APOE allele: A review of the evidence and suggested mechanisms for the protective effect of APOE ع2. Neurosci. Biobehav. Rev. 2013, 37, 2878-2886. [CrossRef] [PubMed]

196. Prins, N.D.; van der Flier, W.A.; Knol, D.L.; Fox, N.C.; Brashear, H.R.; Nye, J.S.; Barkhof, F.; Scheltens, P. The effect of galantamine on brain atrophy rate in subjects with mild cognitive impairment is modified by apolipoprotein E genotype: Post-hoc analysis of data from a randomized controlled trial. Alzheimers Res. Ther. 2014, 6, 47. [CrossRef] [PubMed]

(C) 2019 by the authors. Licensee MDPI, Basel, Switzerland. This article is an open access article distributed under the terms and conditions of the Creative Commons Attribution (CC BY) license (http://creativecommons.org/licenses/by/4.0/). 